Dear Author,

Please, note that changes made to the HTML content will be added to the article before publication, but are not reflected in this PDF.

Note also that this file should not be used for submitting corrections. 


\section{Q2 A complex magmatic system beneath the Kissomlyó monogenetic volcano (western Pannonian Basin): Evidence from mineral textures, zoning and chemistry}

a MTA-ELTE Volcanology Research Group, Pázmány Péter sétány 1/C, H-1117 Budapest, Hungary

b Vulcano Research Group, Department of Mineralogy, Geochemistry and Petrology, University of Szeged, Egyetem utca 2, H-6722 Szeged, Hungary

c Department of Petrology and Geochemistry, Eötvös Loránd University, Pázmány Péter sétány 1/C, H-1117 Budapest, Hungary

d Volcanic Risk Solutions, Massey University, Private Bag 11 222, Palmerston North, New Zealand

e Department of Lithospheric Research, University of Vienna, Althanstrasse 14, A-1090 Vienna, Austria

\section{A R T I C L E I N F O}

\section{Article history:}

Received 17 October 2014

Accepted 24 April 2015

Available online xxxx

\section{Keywords:}

Alkaline basalt

Magma storage

Monogenetic volcano

Olivine

Open-system processes

Spinel

\begin{abstract}
A B S T R A C T
Kissomlyó is a small-volume Pliocene alkaline basaltic eruptive centre located in the monogenetic Little 22 Hungarian Plain Volcanic Field (western Pannonian Basin). It consists of a sequence of pyroclastic and 23 effusive eruptive units: early tuff ring (unit 1), pillow and columnar jointed lava (unit 2), spatter cone 24 (unit 3). The tuff ring sequence is overlain by a unit of lacustrine sediments which suggests a significant 25 time gap in the volcanic activity between the tuff ring formation and the emplacement of the lava flow. 26 High-resolution investigation of mineral textures, zoning and chemistry as well as whole-rock geochemical 27 analyses were performed on stratigraphically controlled samples in order to characterise the magmas 28 represented by the distinct eruptive units and to reveal the evolution of the deep magmatic system. 29 Based on the bulk rock geochemistry, compositionally similar magmas erupted to the surface during the entire 30 volcanic activity. However, olivine crystals show diverse textures, zoning patterns and compositions reflecting 31 various deep-seated magmatic processes. Five different olivine types occur in the samples. Type 1 olivines 32 represent the phenocryst sensu stricto phases, i.e., crystallised in situ from the host magma. The other olivine 33 types show evidence for textural and compositional disequilibrium reflecting single crystals consisting of distinct 34 portions having different origins. Type $2 \mathrm{a}$ and type $2 \mathrm{~b}$ olivines have antecrystic cores which are derived from two 35 distinct primitive magmas based on the different compositions of their spinel inclusions. Type 4 olivines show 36 reverse zoning whose low-Fo cores represent antecrysts from more evolved magmas. The cores of type 3 and 37 type 5 olivines are xenocrysts originated from the subcontinental lithospheric mantle. These xenocrysts are 38 surrounded by high-Fo or low-Fo growth zones suggesting that olivine xenocryst incorporation occurred at 39 different levels and stages of magma evolution.

Olivine-hosted spinel inclusions show three distinct compositional groups. Group 1 spinels are very Al-rich 41 (0-0.22 Cr\#) and coexist with the antecrystic cores of type 2a olivines, group 2 spinels have 44.5-62.3 Cr\#s 42 and occur in the phenocryst s.s. (type 1 ) olivines, while group 3 spinels are very rich in $\mathrm{Cr}$ (68.4-81.3 $\mathrm{Cr} \#) 43$ and appear in the antecrystic cores of type $2 \mathrm{~b}$ olivines. Based on the integrated analysis of olivines and their 44 spinel inclusions four magmatic environments were involved into the evolution of the magmatic system. 45 These crystals bear evidence of various petrogenetic processes playing role in the formation of the erupted 46 magma batches: fractional crystallization, olivine ( + spinel) recycling, xenocryst incorporation, magma 47 recharge and interaction of multiple small magma packets in a multi-level magmatic system.

Clinopyroxene-melt thermobarometry yields an average pressure of $6.6 \pm 0.9 \mathrm{kbar}$ corresponding to a depth of 49 about $25 \mathrm{~km}$, implying that the main level of final clinopyroxene fractionation could have occurred around the 50 Moho (in the lowermost crust).

This study shows that high-resolution mineral-scale analyses carried out through monogenetic sequences 52 provide a unique, more detailed insight into the evolution of these "simple" magmatic systems as crystal growth 53 stratigraphy and compositions yield direct evidence for various petrogenetic processes which are usually 54 obscured in the whole-rock geochemistry.
\end{abstract}

(c) 2015 Published by Elsevier B.V.

* Corresponding author at: Pázmány Péter sétány 1/C, H-1117 Budapest, Hungary. Tel.: + 36137225008359.

E-mail address: m.eva.jankovics@gmail.com (M.É. Jankovics). 


\section{Introduction}

Terrestrial basaltic volcanic fields generally contain numerous small edifices of cinder cones, tuff rings, maars, shield volcanoes and lava flows representing small-volume and short-lived monogenetic eruptive centres. Each of these volcanoes is produced by a single episode of volcanic activity lasting from several days to decades and emitting $<1 \mathrm{~km}^{3}$ volumes of magma (e.g., Takada, 1994; Connor and Conway, 2000). On closer inspection, regardless of their small size they often have complex architecture reflecting multiple eruption phases which produced different eruptive units (e.g., Smith et al., 2008; Brenna et al., 2010; Németh, 2010; Sohn et al., 2012). Detailed studies on single volcanic centres revealed significant compositional variations through the sequences and between phases of the eruption that were interpreted as the result of complex melting and mixing processes within the mantle sources, variations in melting conditions or mixing of different magma batches during ascent (e.g., Strong and Wolff, 2003; Brenna et al., 2010, 2011; Erlund et al., 2010; Mcgee et al., 2012; Sohn et al., 2012; Boyce et al., 2015). All of these works rest on whole-rock major and trace element and isotopic compositions, however, less focus has been put on the textures, zoning and chemistry of rock-forming minerals that bear valuable information about the processes acting during the evolution of the magmatic systems (e.g., Streck, 2008). As shown by a number of studies (e.g., Dobosi, 1989; Dobosi et al., 1991; Roeder et al., 2001, 2003, 2006; Reubi et al., 2003; Smith and Leeman, 2005; Jankovics et al., 2009, 2012, 2013; Longpré et al., 2014), the detailed textural and chemical analyses of the phenocryst phases in basaltic rocks can provide unique insights into the details of magma evolution as well as of the mantle source regions.

The Carpathian-Pannonian Region (in Eastern Central Europe) includes several intracontinental monogenetic volcanic fields which are not associated with large-volume composite volcanoes (like for example in the case of Jeju or Etna). They were formed during the Late Miocene-Quaternary alkaline basalt volcanism (e.g., Embey-Isztin et al., 1993; Harangi, 2001a; Harangi and Lenkey, 2007). A number of eruptive centres of these volcanic fields were the subject of extensive research based on physical volcanology and whole-rock geochemistry (e.g., Embey-Isztin et al., 1993; Harangi et al., 1994, 1995; Konečný et al., 1995; Németh et al., 2001; Martin and Németh, 2004, 2005; Seghedi et al., 2004; Auer et al., 2007; Kereszturi et al., 2010; Ali and Ntaflos, 2011), but only a few of them were studied through both detailed mineral-scale investigations and whole-rock chemical analyses (Dobosi, 1989; Jankovics et al., 2009, 2012, 2013; Harangi et al., 2013). Additionally, there are no examples of detailed studies of petrology and geochemistry of the distinct eruptive units through the succession of a given volcanic centre from this region.

This paper focuses on the Kissomlyó eruptive centre, located in the Little Hungarian Plain Volcanic Field (western Pannonian Basin), which shows a complex volcanological architecture consisting of different eruptive units (tuff ring, lava flows, spatter cone). Based on earlier physical volcanological observations a considerable time break was suggested during its volcanic activity (Martin and Németh, 2004, 2005). As the sedimentary evidences of time breaks in monogenetic eruption sequences are potential indications of shifts in eruption chemistry (e.g., Sohn et al., 2012) our aim was to reveal whether there are significant compositional differences between the magmas erupted to the surface before and after the quiescence period. Monogenetic volcanic centres with intermittent activity are only rarely known. The eruptive units of the well-studied Rangitoto volcano (Auckland Volcanic Field, New Zealand) have been produced by two significantly different-an alkaline and a subalkaline-magma batches, it can be characterised by a $\sim 1000$ years long intermittent activity and it is much more voluminous than Kissomlyó (Mcgee et al., 2011; Needham et al., 2011; Shane et al., 2013). In addition, there are also some examples for rejuvenating activity in the same locations with a difference of several thousand years (western Saudi Arabian volcanic fields; Németh et al., 2014) or even of millions of years (Hammerunterwiesenthal maar, Saxony; Suhr and
Goth, 2013; although here the 2nd and 3rd phases were only represent- 126 ed by subvolcanic intrusions).

Whole-rock composition represents the composition of the erupted 128 magma which in most cases is the result of several closed- and open- 129 system petrogenetic processes involving discrete magma batches of 130 similar/different compositions. We performed high-resolution textural 131 and chemical investigations of the rock-forming minerals because 132 they respond texturally and compositionally to changing magmatic en- 133 vironments and preserve in their crystal growth stratigraphy a wealth 134 of information concerning the magmatic processes and compositions 135 (e.g., Ginibre et al., 2007; Streck, 2008). This mineral-scale study was 136 integrated with the whole-rock geochemistry of stratigraphically con- 137 trolled samples deriving from the three eruptive units of Kissomlyó. 138

\section{Geological setting}

The Pannonian Basin is a Miocene extensional back-arc basin 140 surrounded by the Alpine, Carpathian, and Dinarides orogenic belts 141 (Fig. 1A). It is characterised by thin lithosphere (50-80 km) and crust 142 (22-30 km) coupled with high heat flow ( $>80 \mathrm{~mW} / \mathrm{m}^{2}$; Csontos et al., 143 1992; Fodor et al., 1999; Tari et al., 1999; Bada and Horváth, 2001; 144 Lenkey et al., 2002). These features are due to the initial syn-rift phase 145 (17-12 Ma; Horváth, 1995) of the Pannonian Basin that was 146 characterised by subduction roll-back, related back-arc extension and 147 lithospheric thinning (Csontos et al., 1992; Horváth, 1993; Tari et al., 148 1999). This was followed by the Late Miocene-Pliocene post-rift phase 149 (e.g., Horváth, 1995) which was accompanied by thermal subsidence, 150 thickening of the lithosphere and sedimentation in the basin areas. 151 Tectonic inversion has characterised the Pannonian Basin since the 152 late Pliocene because of the push of the Adriatic plate from the south- 153 west and blocking by the East European platform in the east (Horváth 154 and Cloetingh, 1996).

Post-extensional alkaline basaltic volcanism occurred from 11 to 156 $0.13 \mathrm{Ma}$ in the region, mainly on its marginal parts, which formed 157 monogenetic volcanic fields (Fig. 1A) (e.g., Martin and Németh, 2004; 158 Seghedi et al., 2004; Harangi and Lenkey, 2007). The geodynamic rela- 159 tionships of the alkaline basaltic volcanism are still debated. Several re- 160 searchers suggested that localised mantle plume fingers (deriving from 161 a common mantle reservoir named "European Asthenospheric Reser- 162 voir"; Hoernle et al., 1995) could be responsible for the alkaline basaltic 163 volcanism in Western and Central Europe, accordingly in the Pannonian 164 Basin as well (Granet et al., 1995; Seghedi et al., 2004). However, 165 Harangi and Lenkey (2007), Harangi (2009) and Harangi et al. (2014) Q4 argued against the plume-related magmatism. They suggest that the 167 significantly stretched Pannonian Basin provided suction in the 168 sublithospheric mantle and generated mantle flow from below the 169 thick lithospheric roots (Alps, North European Platform) which could 170 lead to the partial melting of the heterogeneous upper mantle. The 171 relatively hot asthenospheric material could ascend along the steep 172 lithosphere-asthenosphere boundary.

The Little Hungarian Plain Volcanic Field (Fig. 1B) consists of 174 scattered eroded remnants of tuff rings, maars and scoria cones 175 (e.g., Jugovics, 1968; Harangi et al., 1994, 1995; Martin and Németh, 176 2004). These volcanic centers are located along strike-slip faults and 177 near to a detachment fault (Rába line) (e.g., Jugovics, 1915, 1916; Tari 178 et al., 1992). The volcanic activity commenced with trachyandesitic to 179 trachytic volcanism ( 11-12 Ma) and built up a >1000 m thick volcanic 180 complex (Pásztori, northern part of the volcanic field) that is buried by 181 2000 m of Late Miocene to Quaternary sediments (Harangi et al., 1995; 182 Harangi, 2001b). The small basaltic volcanoes in the southern part of the 183 volcanic field were formed during the Early Pliocene based on the earli- 184 er K/Ar radiometric age data ( 4.5-5.9 Ma; Balogh et al., 1986). The 185 ${ }^{40} \mathrm{Ar}{ }^{39} \mathrm{Ar}$ dating carried out in the western part of the Pannonian Basin 186 (Wijbrans et al., 2007) included only the Ság-hegy (5.48 $\pm 0.01 \mathrm{Ma}) 187$ and the Kissomlyó ( $4.63 \pm 0.02 \mathrm{Ma}$ ) eruptive centres from this region. 188 This volcanic field can be regarded as a tectonically controlled field 189 
(after Valentine and Hirano, 2007) that is characterised by very low magma flux, small number of eruptive centres and long (even around $1 \mathrm{Myr}$ ) quiescence periods between the formation of individual small volcanoes.

\section{Volcanological features and eruptive volume}

The Kissomlyó eruptive centre is a complex monogenetic volcano that consists of different eruptive units produced by multiple eruption phases (Fig. 1C). First, phreatomagmatic explosions built up a tuff ring (consisting of a $\sim 20 \mathrm{~m}$ thick sequence of lapilli tuffs and tuffs) in a terrestrial setting which was followed by the cessation of the volcanism and the deposition of lacustrine sediments (a sequence of siltstone and mudstone) in a crater lake. Later the volcanic activity rejuvenated with lava flow emplacement that resulted in the formation of columnar jointed lava and pillow lava intruding the lacustrine sediments (pillows, pillow breccias, peperite) within the crater. Martin and Németh (2004, 2005) already described the tuff ring pyroclastics, lacustrine sediments and lava flow unit. Based on the presence, features and thickness of the crater lake lacustrine unit they estimated the time gap between the tuff ring formation and the emplacement of the lava flow to be in the order of thousands of years. On the top of the volcanic edifice a spatter cone remnant (Királykő) can be found. The ${ }^{40} \mathrm{Ar} /{ }^{39} \mathrm{Ar}$ age of the lava flow unit is $4.63 \mathrm{Ma}$ (Wijbrans et al., 2007). The formation of unit 2 and unit 3 eruptive units can be treated as one main volcanic event after the quiescence period based on their volcanological features.
It would be important to quantify more precisely the time gap be- 214 tween the above-mentioned two eruptive phases therefore we tried 215 to rethink the sedimentary features of the lacustrine unit. As Martin 216 and Németh (2005) have already described, the sedimentary structures 217 of this unit are preserved only in its lower $70 \mathrm{~cm}$, while its other part is 218 disturbed by lava. In the lower undisturbed $\sim 70 \mathrm{~cm}$ it can be observed 219 that the sediment is fine-grained, good sorted and dominantly 220 parallel-laminated indicating suspension settling. It consists of fine 221 ( $1 \mathrm{~mm}$ thick) alternating dark and light laminae. The exact extent of 222 this siliciclastic unit is difficult to determine, but Martin and Németh 223 (2005) estimated its thickness to be maximum $5 \mathrm{~m}$ based on the fact 224 that fluidised sediments occur between the pillows in the entire thick- 225 ness $(\sim 5 \mathrm{~m})$ of the pillow lava. Considering all of these observations 226 they concluded that the lacustrine sedimentation could have taken 227 place over a period of a few thousand years. However, it is notable 228 that there are also some parts of the lacustrine unit characterised by 229 non-uniform, low-angle cross-lamination which imply deposition dur- 230 ing water movement (currents) in addition to the predominate suspen- 231 sion settling. This suggests that the laminae cannot be solely interpreted 232 as the products of cyclic sedimentation but a part of them could have 233 been formed through water movement. In addition, it may be more like- 234 ly that the original thickness of the lacustrine unit should not corre- 235 spond with the whole thickness of the pillow lava but less sediment 236 could have been enough to get everywhere between the pillows during 237 the intense fluidisation. An additional possibility can be that an extreme 238 weather event (e.g., sudden rainfall, intense wind) might have generat- 239 ed the sedimentation in the crater. These latter three arguments can be 240

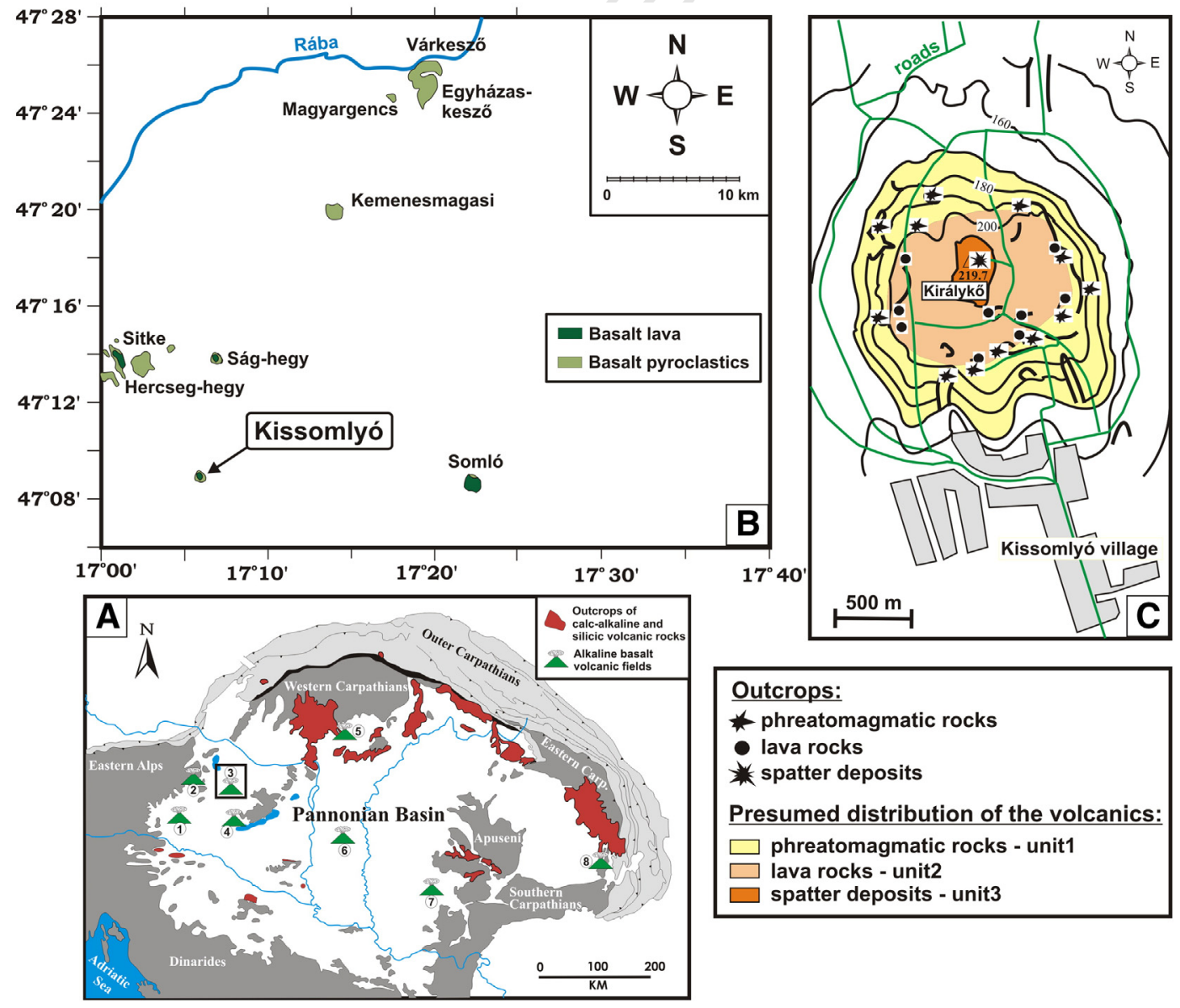

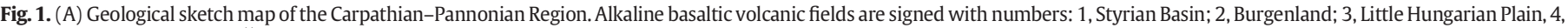

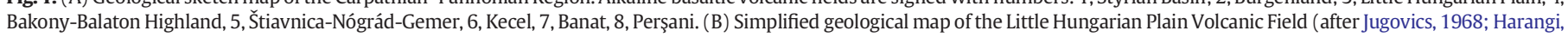
2001c) with the names of the volcanic centres. (C) Map of the Kissomlyó volcano showing the outcrops and distribution of the three eruptive units. Contour intervals are 10 m. 
indicative of a shorter (centuries) time gap between the eruptive phases. Nevertheless, we have to emphasise at this point, that presently there is no unambiguous tool to quantify more precisely the length of this time gap. Therefore, we can conclude now that the quiescence period in the volcanic activity might have lasted for hundreds to thousands of years.

The compound volcanological architecture and the rejuvenation of volcanic activity after a significant pause in the same location imply that this monogenetic volcano could be characterised by a complex evolution and can be regarded as a reactivated eruptive centre.

Concerning the eruptive volume of the Kissomlyó volcanics we carried out a simple geometric model calculation in absence of a LiDAR or other high-resolution topographic dataset. As the Kissomlyó volcano is an erosional remnant the observed volcanics represent significantly smaller volumes than the original eruptive volumes. The erosion remnant morphology was described by Martin and Németh (2005). The tuff ring has a diameter of approximately $800 \mathrm{~m}$ and the thickness of its sequence is $\sim 20 \mathrm{~m}$. Considering the effect of the erosion the bulk volume of the tuff ring could have been around $0.01 \mathrm{~km}^{3}$. The DREcorrected volume was estimated using 30 vol.\% juvenile content and 30 vol.\% vesicularity following the method of Kereszturi et al. (2013) that resulted in a value of about $0.001 \mathrm{~km}^{3}$. The bulk volume of the lava unit (having $400 \mathrm{~m}$ diameter and $\sim 20 \mathrm{~m}$ thickness) can be estimated to around $0.001 \mathrm{~km}^{3}$. Using $10 \mathrm{vol}$.\% for void space and 15 vol.\% vesicularity (also after Kereszturi et al., 2013) the DRE-corrected volume is approximately $0.00064 \mathrm{~km}^{3}$. The volume of the spatter cone remnant is very small and can be added to the volume of the lava flows which means that the post-tuff ring DRE eruptive volume can be around $0.001 \mathrm{~km}^{3}$ similarly to that of the tuff ring. Thus, the total DRE volume of the erupted material can be estimated to be maximum $0.002 \mathrm{~km}^{3}$. This value is comparable with those of the smallest volcanic centres of the Auckland Volcanic Field (Kereszturi et al., 2013) when considering the centres built up by similar eruptive units like 273 Kissomlyó.

\section{Samples and analytical methods}

275

In this study, we carried out stratigraphically controlled sampling: 276 rock samples that were collected from the three different eruptive 277 units: juvenile basalt fragments (cauliflower bombs) and lapilli 278 tuffs from the tuff ring pyroclastics (unit 1), lava samples from the 279 pillow and columnar jointed basalt (unit 2) and scoria and bomb 280 samples from the spatter deposits (unit 3). During the sampling, 281 our aim was to collect representative samples from each of the dis- 282 tinct eruptive units. The tuff ring sequence does not contain any sed- 283 imentary evidences (e.g., discontinuity/truncation surfaces, erosion 284 contacts, event horizons, etc.) which would imply changes or breaks 285 in the course of the deposition (it is a typical sequence of pyroclastic 286 density currents that could have deposited continuously within 287 hours), therefore a few sample can be considered as representative 288 for unit 1 . The poor exposure of unit 2 and unit 3 hindered a more de- 289 tailed sampling.

The petrographic investigations were performed with a Nikon 291 YS2-T polarising microscope and an AMRAY 1830 I/T6 scanning elec- 292 tron microscope at the Department of Petrology and Geochemistry of 293 the Eötvös Loránd University (Budapest, Hungary).

294

Whole-rock major and trace element geochemical compositions 295 were analysed at AcmeLabs (Vancouver, Canada; http://acmelab.com/). 296 Major and minor elements were determined by ICP-emission spectrom- 297 etry and trace elements were analysed by ICP-MS following a lithium 298 borate fusion and dilute acid digestion.

The in situ analyses of the mineral phases and glasses were per- 300 formed using a CAMECA SX100 electron microprobe equipped with 301 four WDS and one EDS at the University of Vienna, Department of 302
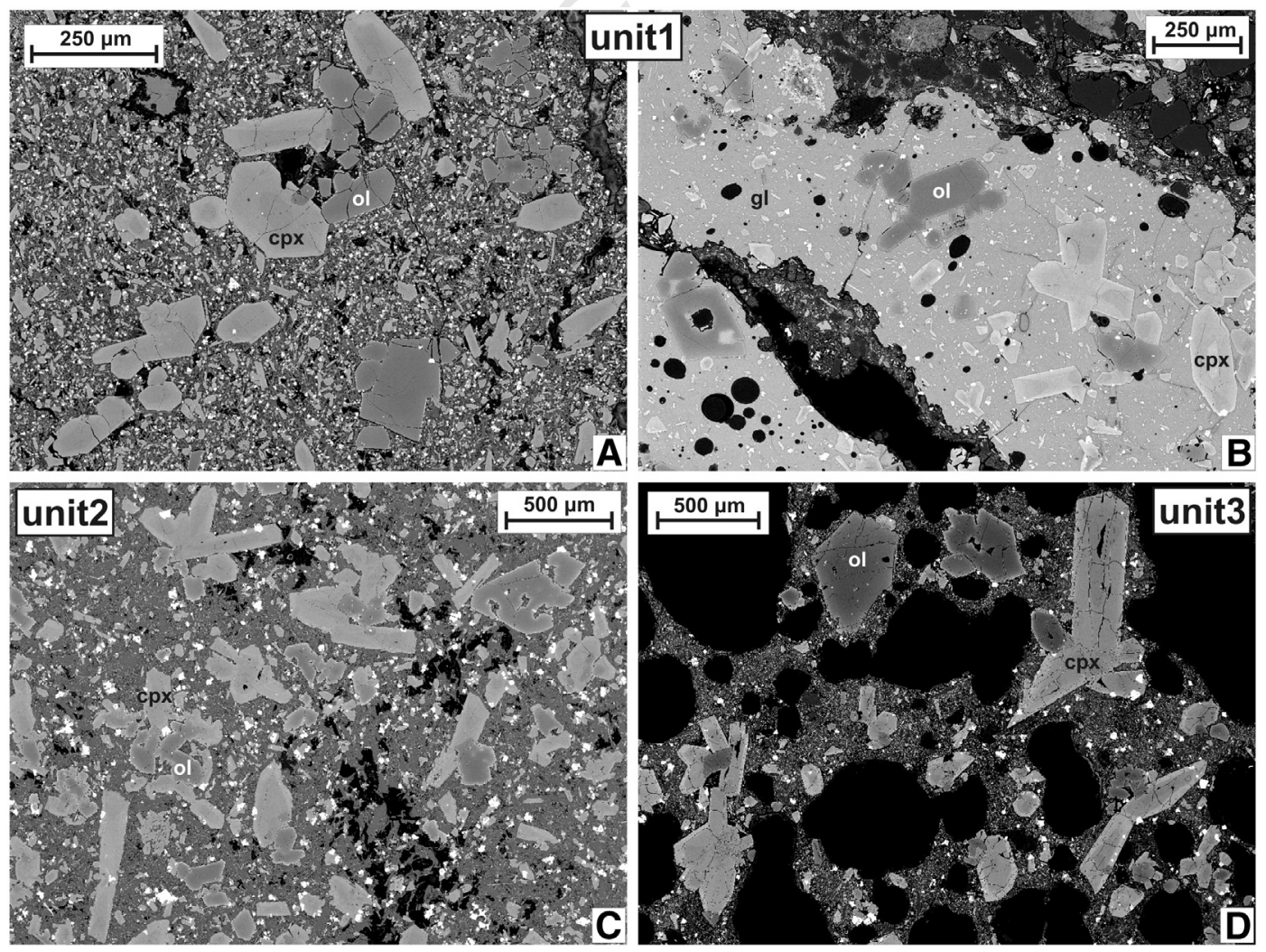

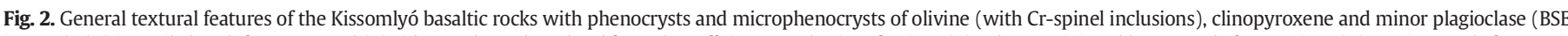

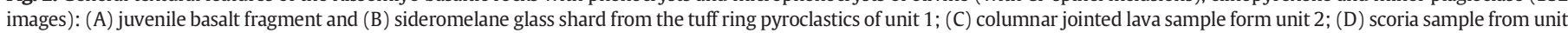
3. Ol, olivine; cpx, clinopyroxene; gl, glass. 
Lithospheric Research (Austria). Operating conditions for minerals were as follows: $15 \mathrm{kV}$ accelerating voltage, $20 \mathrm{nA}$ beam current, $20 \mathrm{~s}$ counting time on peak position, focused beam diameter and PAP correction procedure for data reduction. The same operating conditions with $7 \mu \mathrm{m}$ defocused beam and $10 \mathrm{~s}$ counting time were applied for glass analyses. Calibration was based on the following standards: quartz ( $\mathrm{Si})$, albite $(\mathrm{Na})$, olivine $(\mathrm{Mg})$, almandine $(\mathrm{Al}, \mathrm{Fe})$, wollastonite $(\mathrm{Ca})$, rutile (Ti), spessartine $(\mathrm{Mn})$, orthoclase $(\mathrm{K}), \mathrm{Mg}$-chromite $(\mathrm{Cr})$, Ni-oxide $(\mathrm{Ni})$ and apatite $(\mathrm{P})$.

\section{Petrography}

Each of the studied samples has porphyritic textures with phenocrysts and microphenocrysts of olivine (with spinel inclusions), clinopyroxene (with titanomagnetite inclusions) and minor plagioclase. Compared to the other basaltic rocks of this region, only the Kissomlyó samples contain clinopyroxene as a phenocryst phase. Frequent glomerophyric aggregates of clinopyroxenes, olivines and clinopyroxenes + olivines are also present (Fig. 2). The groundmasses consist of microlitic plagioclase, olivine, clinopyroxene, Fe-Ti-oxides, apatite and glass. Some textural differences can be observed between the samples of the individual eruptive units. The juvenile basalt fragments of unit 1 (Fig. 2A) have medium to highly vesicular textures and are characterised by phenocryst sizes of $<0.8 \mathrm{~mm}$ where only olivine $(<0.8 \mathrm{~mm})$ and clinopyroxene $(<0.65 \mathrm{~mm})$ represent the phenocryst and microphenocryst phases, plagioclase occur only in the fine-grained groundmass. The lapilli tuff samples contain abundant fresh sideromelane glass shards $(0.15-2 \mathrm{~mm}$ in size) which are low to highly vesicular and have the same phenocryst assemblage of olivine and clinopyroxene (Fig. 2B). The textures of the lava rocks of unit 2 (Fig. 2C) have low vesicularity and are coarser-grained compared to the juvenile basalt fragments of unit 1 . Phenocrysts have sizes of $<1.8 \mathrm{~mm}$ (olivine: $<0.9 \mathrm{~mm}$, clinopyroxene: $<1.8 \mathrm{~mm}$, plagioclase: $<0.37 \mathrm{~mm}$ ), and the groundmass is also coarser-grained and have the highest crystallinity (i.e., contain the smallest amount of glass among the studied samples). The scoria and bomb samples of unit 3 (Fig. 2D) have medium to highly vesicular textures and can be characterised by phenocryst sizes of $<1.5 \mathrm{~mm}$ (olivine: $<0.9 \mathrm{~mm}$, clinopyroxene: $<1.5 \mathrm{~mm}$, plagioclase: $<0.16 \mathrm{~mm}$ ) and their groundmass contains a small amount of glass.

Olivine and clinopyroxene often occur together: they are attached to each other or more frequently clinopyroxene surrounds or encloses partly or entirely the olivine (Fig. 2). These features imply that some of the olivines could have crystallised together with the clinopyroxenes, but most of the olivines predated the crystallization of clinopyroxene. In the juvenile basalt fragments of unit 1 there can be also found numerous anhedral quartz xenocrysts (surrounded by tiny clinopyroxenes and glass) and scarce crystal clots of anhedral olivine and orthopyroxene.

\section{Whole-rock geochemistry}

Earlier bulk rock geochemical data for the Kissomlyó volcanic centre were reported by Embey-Isztin et al. (1993) and Harangi et al. (1994, 1995). For our stratigraphically ordered study samples were analysed from each of the three eruptive units: juvenile basalt fragments from the tuff ring sequence (unit 1), pillow and columnar jointed lava (unit 2) and lava spatter deposits (unit 3). The new bulk rock compositions are given in Table 1 (major element abundances are normalised to $100 \%$, the ratio $\mathrm{Fe}_{2} \mathrm{O}_{3} / \mathrm{FeO}$ is set to 0.2 for the calculation of Mg-number). Besides, we have also included and plotted the whole-rock data of Harangi et al. (1995) which represent unit 1 and unit 2 (Fig. 3).

The samples have basanitic, trachybasaltic and basaltic compositions based on their $\mathrm{SiO}_{2}$ and total alkali contents (Fig. 3A). Compared to the other basaltic rocks in the Little Hungarian Plain Volcanic Field all of the Kissomlyó samples show slightly lower Mg\#s (60.4-65.7; $\left.100 * \mathrm{Mg} /\left(\mathrm{Mg}+\mathrm{Fe}^{2+}\right)\right), \mathrm{MgO}(6.9-8.7$ wt.\%) and $\mathrm{Cr}$ contents (189-
Table 1

Bulk rock compositions of the studied samples from the three eruptive units.

\begin{tabular}{|c|c|c|c|c|c|c|c|}
\hline & \multicolumn{2}{|l|}{ Unit 1} & \multicolumn{2}{|l|}{ Unit 2} & \multicolumn{3}{|l|}{ Unit 3} \\
\hline & KS01 & KS02 & KS03 & KS04 & KS05 & KS06 & KS07 \\
\hline $\mathrm{SiO}_{2}$ & 46.30 & 45.75 & 45.66 & 45.90 & 46.29 & 46.43 & 45.89 \\
\hline $\mathrm{TiO}_{2}$ & 2.37 & 2.43 & 2.35 & 2.40 & 2.44 & 2.48 & 2.44 \\
\hline $\mathrm{Al}_{2} \mathrm{O}_{3}$ & 15.38 & 15.93 & 15.04 & 15.56 & 15.28 & 15.54 & 15.77 \\
\hline $\mathrm{FeO}$ & 7.95 & 8.24 & 8.31 & 8.60 & 8.42 & 9.09 & 8.66 \\
\hline $\mathrm{Fe}_{2} \mathrm{O}_{3}$ & 1.59 & 1.65 & 1.66 & 1.72 & 1.68 & 1.82 & 1.73 \\
\hline $\mathrm{MnO}$ & 0.16 & 0.15 & 0.17 & 0.19 & 0.17 & 0.18 & 0.17 \\
\hline $\mathrm{MgO}$ & 6.92 & 7.07 & 8.32 & 8.65 & 8.59 & 8.73 & 8.25 \\
\hline $\mathrm{CaO}$ & 11.55 & 10.96 & 9.61 & 9.63 & 9.82 & 9.87 & 10.05 \\
\hline $\mathrm{Na}_{2} \mathrm{O}$ & 3.87 & 3.19 & 4.43 & 2.57 & 2.82 & 2.22 & 2.63 \\
\hline $\mathrm{K}_{2} \mathrm{O}$ & 1.97 & 2.64 & 2.56 & 2.90 & 2.61 & 1.78 & 2.48 \\
\hline $\mathrm{P}_{2} \mathrm{O}_{5}$ & 1.04 & 1.01 & 0.89 & 0.91 & 0.89 & 0.81 & 0.92 \\
\hline Mg\# & 60.80 & 60.48 & 64.10 & 64.19 & 64.53 & 63.12 & 62.93 \\
\hline $\mathrm{Ni}$ & 84 & 94 & 114 & 113 & 117 & 127 & 115 \\
\hline $\mathrm{Cr}$ & 203 & 189 & 236 & 254 & 246 & 263 & 250 \\
\hline Co & 33.1 & 34.9 & 40.0 & 37.9 & 40.2 & 39.5 & 34.1 \\
\hline Sc & 17 & 19 & 18 & 19 & 19 & 19 & 19 \\
\hline V & 200 & 201 & 212 & 200 & 216 & 218 & 190 \\
\hline Cs & 8.6 & 0.8 & 0.7 & 1.2 & 1.1 & 0.7 & 0.9 \\
\hline $\mathrm{Rb}$ & 117.3 & 60.0 & 60.5 & 65.5 & 60.0 & 32.8 & 53.9 \\
\hline $\mathrm{Ba}$ & 931 & 979 & 867 & 856 & 921 & 863 & 1438 \\
\hline $\mathrm{Sr}$ & 985 & 1000 & 958 & 1020 & 988 & 938 & 1517 \\
\hline La & 53.8 & 52.1 & 52.3 & 54.4 & 53.2 & 51.6 & 55.5 \\
\hline $\mathrm{Ce}$ & 104.8 & 102.0 & 104.6 & 108.2 & 104.6 & 101.5 & 104.7 \\
\hline $\mathrm{Pr}$ & 11.71 & 11.53 & 11.75 & 12.89 & 11.76 & 11.66 & 12.99 \\
\hline $\mathrm{Nd}$ & 45.1 & 45.6 & 45.2 & 50.3 & 47.4 & 47.5 & 51.8 \\
\hline $\mathrm{Sm}$ & 8.05 & 7.80 & 8.04 & 8.76 & 8.24 & 8.04 & 8.67 \\
\hline $\mathrm{Eu}$ & 2.35 & 2.31 & 2.40 & 2.56 & 2.45 & 2.46 & 2.59 \\
\hline Gd & 6.87 & 6.89 & 6.96 & 7.03 & 6.95 & 6.90 & 7.25 \\
\hline $\mathrm{Tb}$ & 0.97 & 0.94 & 0.96 & 0.84 & 0.97 & 0.97 & 0.87 \\
\hline Dy & 4.81 & 4.79 & 4.82 & 5.18 & 4.70 & 4.77 & 5.11 \\
\hline Ho & 0.84 & 0.84 & 0.84 & 0.85 & 0.82 & 0.84 & 0.87 \\
\hline $\mathrm{Er}$ & 2.05 & 2.02 & 2.13 & 2.22 & 2.11 & 1.98 & 2.19 \\
\hline $\mathrm{Tm}$ & 0.30 & 0.29 & 0.29 & 0.32 & 0.29 & 0.29 & 0.30 \\
\hline $\mathrm{Yb}$ & 1.74 & 1.73 & 1.74 & 1.78 & 1.74 & 1.73 & 1.81 \\
\hline $\mathrm{Lu}$ & 0.27 & 0.25 & 0.25 & 0.26 & 0.25 & 0.24 & 0.26 \\
\hline $\mathrm{Hf}$ & 6.60 & 6.80 & 6.30 & 7.40 & 6.50 & 6.80 & 7.50 \\
\hline $\mathrm{Nb}$ & 76.7 & 75.7 & 78.3 & 84.5 & 79.9 & 77.3 & 83.5 \\
\hline Та & 4.70 & 4.50 & 4.90 & 4.80 & 4.90 & 4.60 & 5.40 \\
\hline Th & 9.30 & 9.10 & 8.50 & 8.50 & 8.90 & 8.40 & 9.20 \\
\hline $\mathrm{U}$ & 2.20 & 2.30 & 2.80 & 2.40 & 2.40 & 1.70 & 2.60 \\
\hline $\mathrm{Pb}$ & 12.1 & 14.5 & 29.9 & 7.5 & 9.3 & 10.4 & 7.6 \\
\hline $\mathrm{Zr}$ & 279 & 277 & 278 & 295 & 285 & 279 & 284 \\
\hline Y & 23.8 & 22.9 & 23.0 & 26.2 & 23.8 & 23.7 & 26.3 \\
\hline
\end{tabular}

Major elements are in wt.\%; minor and trace elements are in ppm. Analyses are t2.48 recalculated to $100 \%$ loss free.

$\mathrm{Mg} \#=100 * \mathrm{Mg} /\left(\mathrm{Mg}+\mathrm{Fe}^{2+}\right)$, where $\mathrm{Mg}$ and $\mathrm{Fe}^{2+}$ are cation fractions; $\mathrm{Fe}^{2+}$ is calculated assuming $\mathrm{Fe} 2 \mathrm{O} 3 / \mathrm{FeO}=0.2$.

$263 \mathrm{ppm}$ ) and significantly lower Ni concentrations (84-127 ppm) 365 indicating that they represent more differentiated magmas (as it was 366 also noted by Harangi et al., 1995). Fig. 3B shows that the studied 367 compositions of each eruptive unit of Kissomlyó show very similar 368 chondrite-normalised REE patterns, which are characteristic for basalt 369 compositions in intraplate settings. From unit 2-unit 3 (which compo- 370 sitions almost entirely overlap with each other) to unit 1 the samples 371 show decreasing $\mathrm{MgO}, \mathrm{Cr}$ and $\mathrm{Ni}$ contents as well as almost constant 372 $\mathrm{Al}_{2} \mathrm{O}_{3} / \mathrm{CaO}$ ratios and $\mathrm{Nd}$ concentrations (Fig. 3C-F).

373

When comparing the compositional variation from unit 1 to unit 3374 (1.8 wt.\% MgO, $75 \mathrm{ppm} \mathrm{Cr}$ and $44 \mathrm{ppm} \mathrm{Ni}$ ) with those described through 375 the successions/time of other volcanic centres from other monogenetic 376 fields, it can be observed that the intra-centre chemical variation of 377 Kissomlyó is smaller than each of the others (Fig. 4).

\section{Mineral textures, zoning and chemistry}

In order to characterise and compare the distinct eruptive units in 380 more detail, careful analyses of mineral textures, zoning and composi- 381 tions were performed from all of the three units. Compositions of 382 
$\mathrm{Na}_{2} \mathrm{O}+\mathrm{K}_{2} \mathrm{O}$


Rock/Chondrites

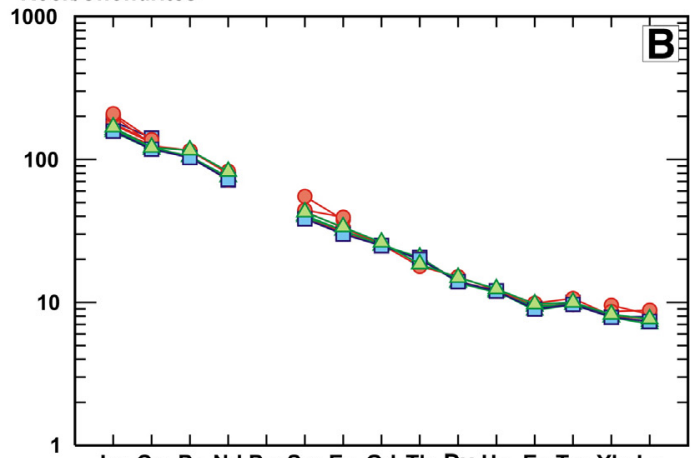

La Ce Pr Nd Pm Sm Eu Gd Tb Dy Ho Er Tm Yb Lu
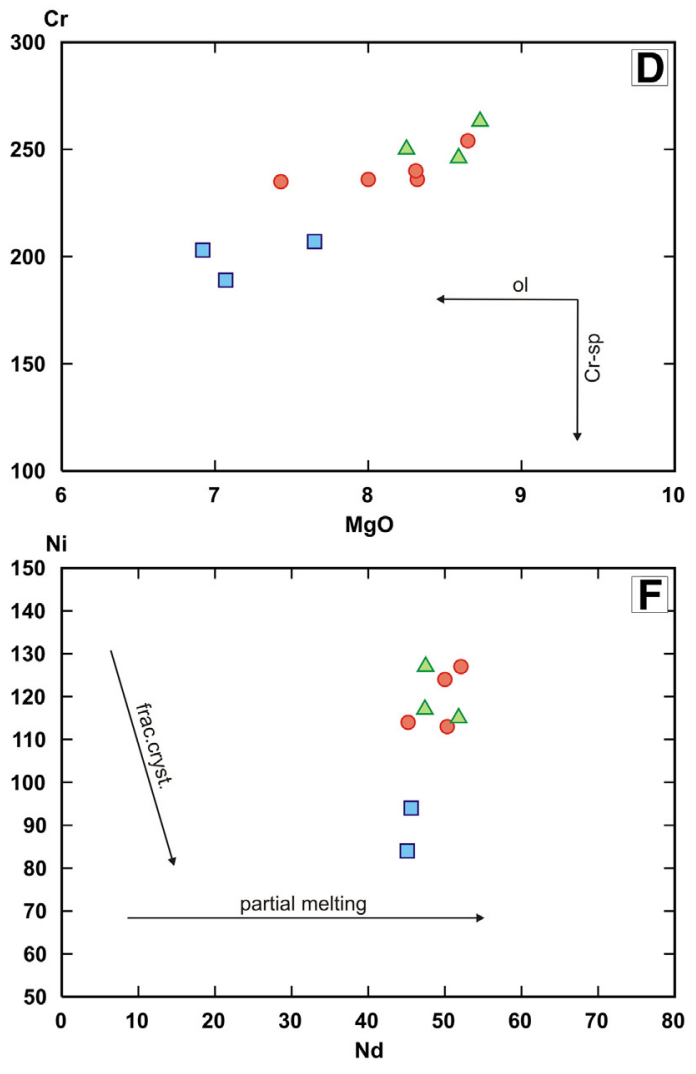

olivine, spinel and clinopyroxene crystals (Fig. 5) as well as glasses were analysed from juvenile basalt fragments and fresh sideromelane glass shards of unit 1, from lava samples of unit 2 and from scoria and bomb samples of unit 3 .

\subsection{Olivine}

Olivine crystals of the studied rocks show variable textures, zoning patterns and compositions; five different types can be distinguished: type 1, type 2 , type 3 , type 4 and type 5 olivines (Fig. 6 ). Type 1 olivines (Fig. 6A) are normally zoned, euhedral-subhedral, often skeletal with $\mathrm{Fo}_{81-86}$ cores and $\mathrm{Fo}_{75-85}$ rims. From their cores to rims, they have increasing $\mathrm{CaO}$ (from $0.16-0.36 \mathrm{wt} . \%$ to $0.23-0.46 \mathrm{wt} . \%$ ) and decreasing $\mathrm{NiO}$ contents (from $0.12-0.31$ wt.\% to $0.08-0.22$ wt.\%). Type 2 olivines (Fig. 6B) are normally zoned, euhedral to subhedral, and they have subhedral-anhedral $\mathrm{Fo}_{86-95}$ cores and often skeletal $\mathrm{Fo}_{80-85}$ rims. Their cores contain $0.10-0.62$ wt.\% $\mathrm{CaO}$ and $0-0.41$ wt.\% NiO, while their 397 rims have $0.25-0.48$ wt.\% $\mathrm{CaO}$ and $0.09-0.21 \mathrm{wt} . \% \mathrm{NiO}$ contents. The 398 type 2 olivine crystals can be divided into two subtypes-type 2a and 399 type $2 \mathrm{~b}$-based on the chemistry of the spinel inclusions in the cores 400 of the host olivines: the cores of type 2a olivines contain Al-rich spinels, 401 while those of type $2 \mathrm{~b}$ olivines have $\mathrm{Cr}$-rich spinels (Fig. 8B, D). Type 3402 olivines (Fig. 6C) have normal zoning; they are euhedral to anhedral 403 and contain 89-91 mol\% Fo in their anhedral cores (often with irregular 404 shapes) and $79-85 \mathrm{~mol} \%$ Fo in their often skeletal rims. The cores have 405 $0.02-0.05$ wt.\% $\mathrm{CaO}$ and $0.34-0.45$ wt.\% NiO concentrations, whereas 406 the rims contain $0.28-0.31$ wt.\% $\mathrm{CaO}$ and $0.11-0.23$ wt.\% NiO. Type 4 ol- 407 ivines (Fig. 6D, E) are reversely zoned, euhedral to subhedral; they have 408 subhedral-anhedral (rarely patchy) cores and their rims are frequently 409 skeletal. Their cores have Fo contents varying between 66 and $85 \mathrm{~mol} \%, 410$ which are either surrounded by only a (10-40 $\mu$ m thick) Mg-richer rim 411 of 82-84 mol\% Fo or by a normally zoned rim Fo $76-86$ (i.e., a 20-60 $\mu \mathrm{m} 412$ 


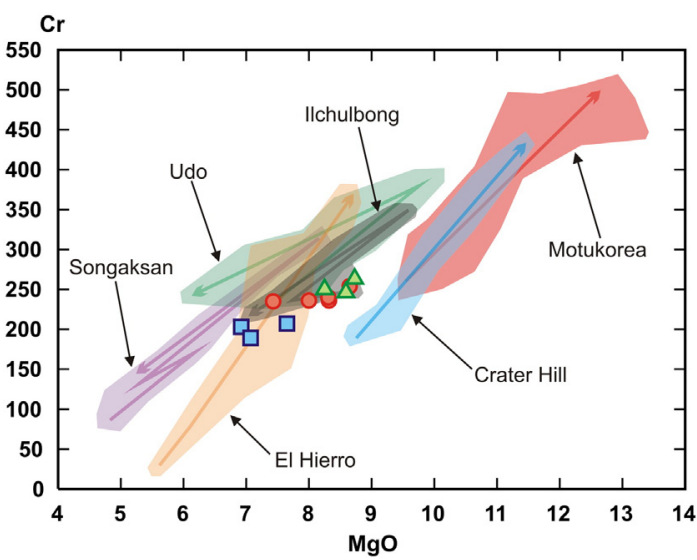

Fig. 4. $\mathrm{MgO}$ (wt.\%) vs. $\mathrm{Cr}$ (ppm) plot showing the chemical variations through time/ successions also in the case of other monogenetic volcanoes: Crater Hill (Smith et al 2008) and Motukorea (Mcgee et al., 2012), Auckland Volcanic Field; Udo (Brenna et al., 2010), Songaksan (Brenna et al., 2011) and Ilchulbong (Sohn et al., 2012), Jeju Island Volcanic Field; El Hierro, 2011-2012 activity, Canary Islands (Martí et al., 2013). Symbols for the Kissomlyó data as in Fig. 3.

thick growth band of $\mathrm{Fo}_{80-86}$ and a $10-40 \mu \mathrm{m}$ final rim $\left.\mathrm{Fo}_{76-84}\right)$. They contain $0.10-0.31 \mathrm{wt} . \% \mathrm{CaO}$ and $0.02-0.27 \mathrm{wt} . \% \mathrm{NiO}$ in the cores, and $0.22-0.39$ wt.\% $\mathrm{CaO}$ and $0.08-0.27$ wt.\% NiO in the rims. Type 5 olivines (Fig. 6F) are multiple-zoned; they have an anhedral rounded core of $\mathrm{Fo}_{89-90}, 0.02-0.03$ wt.\% $\mathrm{CaO}$ and $0.36-0.38$ wt.\% $\mathrm{NiO}$ (with rare orthopyroxene inclusions) that is surrounded by a growth zone of $\mathrm{Fo}_{83-85}, 0.22-0.24 \mathrm{wt} . \% \mathrm{CaO}, 0.18-0.22 \mathrm{wt}$.\% $\mathrm{NiO}$ and a normally zoned skeletal rim of $\mathrm{Fo}_{82-86}, 0.22-0.38$ wt.\% $\mathrm{CaO}$ and $0.10-0.25$ wt.\% NiO. Fig. 7 shows the different core-to-rim compositional variations observed within type 1 , type 2 , type 3 , type 4 and type 5 olivine crystals. Representative olivine compositions are given in Table 2.

Olivine crystals of the five different types occur in the samples of each eruptive unit. Type 1 olivines are the most common ones in each sample. The sideromelane glass shards of unit 1 contain only type 1 olivines. Type 2, type 3 and type 5 olivines occur with very similar frequencies in the three eruptive units, however, type 4 crystals are much more frequent in the juvenile basalt fragments of unit 1 (their amount is twice as much as in the unit 2-unit 3 samples). Type 2a olivines are present in the samples of unit 2 and unit 3 , and type $2 \mathrm{~b}$ olivines were found in those of unit 1 and unit 2. Unit 1 samples can be characterised by the broadest range of olivine Fo contents (66$91 \mathrm{~mol} \%$ ) caused by the variety of the cores of the type 4 (reversely zoned) crystals that is much more limited in unit 2 and unit 3.

\subsection{Spinel}

Spinels occur as inclusions in several portions of each olivine type: in all parts of type 1 olivines, in the cores and rims of type $2 \mathrm{a}$ and type $2 \mathrm{~b}$ olivines, and in the rims of type 3, type 4 and type 5 crystals (Figs. 6 and 8 ). The cores of type 3 , type 4 and type 5 olivines do not contain any spinel inclusions in the studied samples. The sizes of the spinels range from 2 to $20 \mu \mathrm{m}$; they are euhedral to subhedral crystals and have a homogeneous interior. Based on their locations and characteristics, three spinel groups can be distinguished. Group 1 spinels (occurring in unit 2 and unit 3 samples) have a light green colour; they are very Al-rich (57.363.1 wt.\% $\mathrm{Al}_{2} \mathrm{O}_{3}$ and 0-0.21 wt.\% $\left.\mathrm{Cr}_{2} \mathrm{O}_{3}\right)$; their $\mathrm{Cr} \# \mathrm{~s}(100 * \mathrm{Cr} /(\mathrm{Cr}+\mathrm{Al}))$ are very low $(0-0.22)$ and contain $0.03-3.3 \mathrm{wt} . \% \mathrm{TiO}_{2}$ (Fig. $8 \mathrm{C}$ ). They occur only in the cores of type 2a olivines (Figs. 6B and 8D). Group 2 spinels (occurring in the samples of each unit) represent the dominant spinel group; they are light brown, have 10.9-23 wt.\% $\mathrm{Al}_{2} \mathrm{O}_{3}$ and 14.834.3 wt.\% $\mathrm{Cr}_{2} \mathrm{O}_{3}$ concentrations; their $\mathrm{Cr} \#$ varies from 44.5-62.3 and show variable $\mathrm{TiO}_{2}$ contents (1.9-7.2 wt.\%) (Fig. 8C). They are present in all portions of type 1 olivines (Figs. $6 \mathrm{~A}$ and $8 \mathrm{~A}$ ), in the rims of type
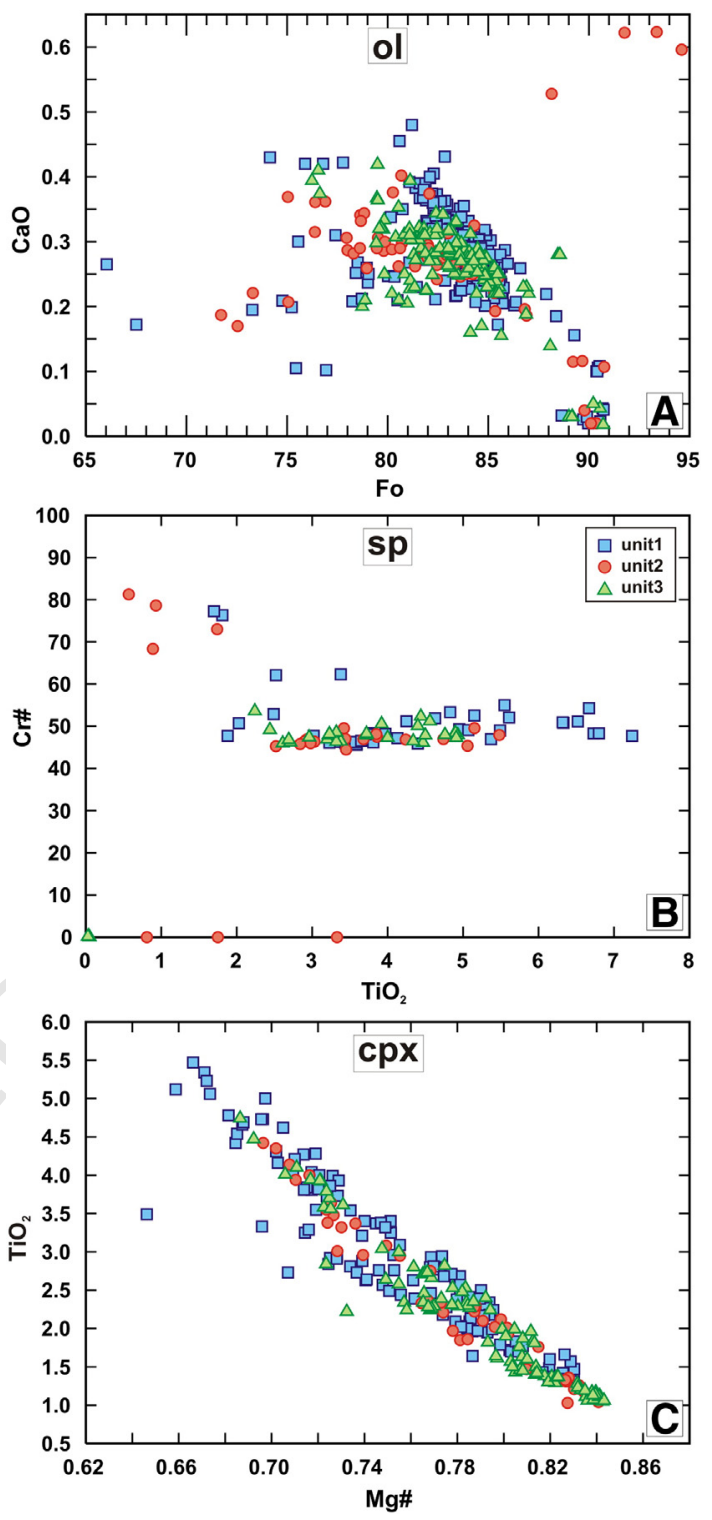

Fig. 5. Mineral compositions of the Kissomlyó samples from the three eruptive units: (A) olivine Fo (mol\%) vs. $\mathrm{CaO}$ (wt.\%) plot; (B) spinel $\mathrm{TiO}_{2}$ (wt.\%) vs. $\mathrm{Cr} \#\left(100^{*} \mathrm{Cr} /(\mathrm{Cr}+\mathrm{Al})\right)$ diagram; (C) clinopyroxene $\mathrm{Mg} \#\left(\mathrm{Mg} /\left(\mathrm{Mg}+\mathrm{Fe}^{\mathrm{tot}}\right)\right)$ vs. $\mathrm{TiO}_{2}$ (wt.\%) variation.

2a and type 2b olivines (Fig. 8B, D), as well as in the rims of type 3454 (Fig. 6C), type 4 (Figs. 6D and 8E) and type 5 (Fig. 6F) crystals. Group 455 3 spinels (occurring in unit 1 and unit 2 samples) are dark brown 456 to black; they are very rich in $\mathrm{Cr}$ (41.4-51.1 wt.\% $\mathrm{Cr}_{2} \mathrm{O}_{3}$ and 7.9- 457 12.9 wt.\% $\mathrm{Al}_{2} \mathrm{O}_{3}$ ); their $\mathrm{Cr} \# \mathrm{~s}$ are the highest (68.4-81.3) and contain 458 $0.57-1.8 \mathrm{wt} . \% \mathrm{TiO}_{2}$ (Fig. 8C). They occur only in the cores of type $2 \mathrm{~b} 459$ olivines (Fig. 8B). It is important to note that in the case of type $2 \mathrm{a} 460$ and type $2 \mathrm{~b}$ olivine crystals spinels of the distinct compositional groups 461 were found to be inclusions within the same olivine crystals (Fig. 8B, D). 462 Representative spinel compositions are presented in Table 3.

463

\subsection{Clinopyroxene}

Clinopyroxene phenocrysts are euhedral to subhedral and most often 465 appear as glomerocrysts. They frequently contain olivine crystals as inclu- 466 sions (Fig. 9A) or partly enclose them (Fig. 9B). Characteristically they 467 show sector zoning that displays highly variable appearances and usu- 468 ally, oscillatory zoning is associated with hour-glass zoning (Fig. 9A, B). 469 



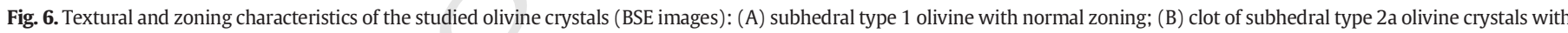

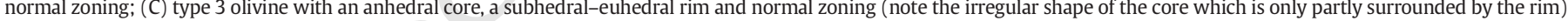

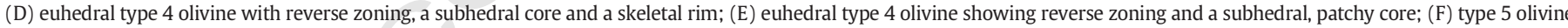

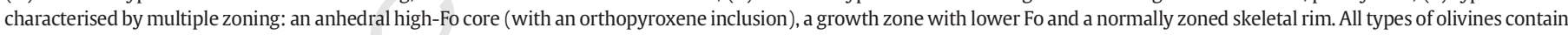
spinel inclusions in some of their portions: sp1 and sp2 refers to group 1 and group 2 spinels, respectively seen in Fig. 8. Sp, spinel; opx, orthopyroxene.
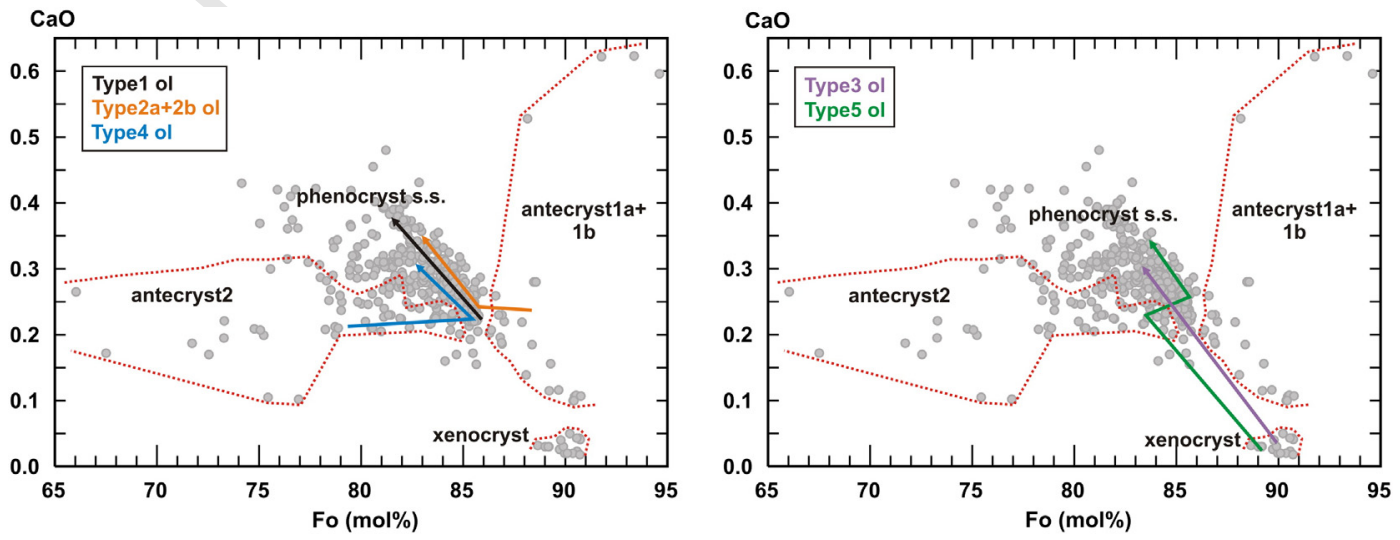

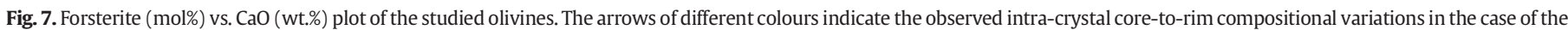
five different olivine types. Antecryst $1 \mathrm{a}+1 \mathrm{~b}$, antecryst 2 , xenocryst and phenocryst s.s. refer to the distinct origins of olivines (see text for explanation), 
Table 2

Representative compositions of the studied olivine crystals.

\begin{tabular}{|c|c|c|c|c|c|c|c|c|c|c|c|c|c|c|c|c|c|c|c|}
\hline & \multicolumn{8}{|c|}{ Type 1 olivine } & \multicolumn{8}{|c|}{ Type 2 olivine } & \multicolumn{3}{|c|}{ Type 3 olivine } \\
\hline & Core & Rim & Core & Rim & Core & Rim & Core & Rim & Core & $\operatorname{Rim}$ & Core & Rim & Core & $\operatorname{Rim}$ & Core & Rim & Core & Rim & Core \\
\hline & ol1_1 & ol1_2 & ol2_1 & ol2_2 & ol3_1 & ol3_2 & ol4_1 & ol4_2 & ol5_1 & ol5_2 & ol6_1 & ol6_2 & ol7_1 & ol7_2 & ol8_1 & ol8_2 & ol9_1 & ol9_2 & $\overline{\text { ol10_1 }}$ \\
\hline $\mathrm{SiO}_{2}$ & 39.98 & 39.32 & 39.86 & 39.02 & 39.31 & 38.97 & 40.96 & 39.54 & 40.92 & 39.50 & 40.38 & 40.00 & 40.49 & 39.64 & 41.19 & 39.67 & 41.16 & 40.06 & 40.92 \\
\hline $\mathrm{MgO}$ & 45.18 & 43.56 & 44.54 & 41.28 & 43.11 & 39.82 & 48.43 & 43.62 & 47.55 & 42.42 & 46.42 & 44.54 & 47.63 & 44.00 & 48.69 & 43.08 & 49.40 & 45.50 & 48.54 \\
\hline $\mathrm{FeO}^{\text {tot }}$ & 13.88 & 15.49 & 15.01 & 18.58 & 16.36 & 20.02 & 9.94 & 15.94 & 11.06 & 16.99 & 12.50 & 14.28 & 11.17 & 15.62 & 9.41 & 16.44 & 9.17 & 14.20 & 9.51 \\
\hline $\mathrm{CaO}$ & 0.21 & 0.30 & 0.26 & 0.33 & 0.24 & 0.29 & 0.12 & 0.31 & 0.28 & 0.29 & 0.19 & 0.27 & 0.19 & 0.31 & 0.05 & 0.31 & 0.02 & 0.28 & 0.02 \\
\hline $\mathrm{NiO}$ & 0.26 & 0.13 & 0.24 & 0.12 & 0.16 & 0.10 & 0.30 & 0.17 & 0.11 & 0.16 & 0.19 & 0.20 & 0.35 & 0.16 & 0.39 & 0.16 & 0.41 & 0.23 & 0.38 \\
\hline $\mathrm{MnO}$ & 0.27 & 0.31 & 0.28 & 0.37 & 0.29 & 0.42 & 0.14 & 0.27 & 0.19 & 0.29 & 0.24 & 0.27 & 0.17 & 0.28 & 0.14 & 0.30 & 0.16 & 0.26 & 0.13 \\
\hline Total & 99.93 & 99.17 & 100.27 & 99.83 & 99.64 & 99.71 & 99.97 & 99.95 & 100.21 & 99.75 & 99.98 & 99.63 & 100.07 & 100.06 & 99.88 & 100.04 & 100.35 & 100.60 & 99.52 \\
\hline Fo (mol\%) & 85.29 & 83.36 & 84.10 & 79.83 & 82.45 & 78.00 & 89.67 & 82.99 & 88.46 & 81.66 & 86.88 & 84.76 & 88.37 & 83.39 & 90.22 & 82.36 & 90.57 & 85.10 & 90.10 \\
\hline
\end{tabular}

$\mathrm{FeO}^{\mathrm{tot}}=$ total amount of iron; ol $=$ olivine.

Table 2 (continued)

.

rable 2 (continued)

\begin{tabular}{|c|c|c|c|c|c|c|c|c|c|c|c|c|c|c|c|c|c|c|c|}
\hline & \multicolumn{5}{|c|}{ Type 3 olivine } & \multicolumn{6}{|c|}{ Type 4 olivine } & \multicolumn{8}{|c|}{ Type 5 olivine } \\
\hline & \multirow{2}{*}{$\frac{\operatorname{Rim}}{\text { ol10_2 }}$} & \multirow{2}{*}{$\frac{\text { Core }}{\text { ol11_1 }}$} & \multirow{2}{*}{$\frac{\operatorname{Rim}}{\text { ol11_2 }}$} & \multirow{2}{*}{$\frac{\text { Core }}{\text { ol12_1 }}$} & \multirow{2}{*}{$\frac{\text { Rim }}{\text { ol12_2 }}$} & \multirow{2}{*}{$\frac{\text { Core }}{\text { ol13_1 }}$} & \multicolumn{2}{|c|}{ Normally zoned rim } & \multirow{2}{*}{$\frac{\text { Core }}{\text { ol14_1 }}$} & \multicolumn{2}{|c|}{ Normally zoned rim } & \multirow{2}{*}{$\begin{array}{l}\text { Core } \\
\text { ol15_1 }\end{array}$} & \multirow{2}{*}{$\frac{\text { Growth zone }}{\text { ol15_2 }}$} & \multicolumn{2}{|c|}{ Normally zoned rim } & \multirow{2}{*}{$\frac{\text { Core }}{\text { ol16_1 }}$} & \multirow{2}{*}{$\frac{\text { Growth zone }}{\text { ol16_2 }}$} & \multicolumn{2}{|c|}{ Normally zoned rim } \\
\hline & & & & & & & ol13_2 & ol13_3 & & $\overline{\text { ol14_2 }}$ & $\overline{\text { ol14_3 }}$ & & & ol15_3 & $\overline{\text { ol15_4 }}$ & & & ol16_3 & ol16_4 \\
\hline $\mathrm{SiO}_{2}$ & 39.59 & 37.10 & 39.17 & 39.55 & 39.83 & 38.81 & 39.82 & 39.30 & 37.35 & 38.87 & 38.04 & 40.94 & 39.65 & 40.00 & 39.77 & 41.11 & 40.15 & 40.20 & 39.78 \\
\hline $\mathrm{MgO}$ & 42.75 & 33.34 & 42.60 & 44.01 & 45.31 & 41.66 & 44.53 & 41.98 & 36.07 & 42.13 & 38.87 & 48.39 & 43.15 & 44.79 & 43.92 & 47.75 & 44.30 & 44.99 & 42.87 \\
\hline $\mathrm{FeO}^{\text {tot }}$ & 16.68 & 28.59 & 17.12 & 15.66 & 13.92 & 18.17 & 14.92 & 17.85 & 24.33 & 17.07 & 21.40 & 9.62 & 15.91 & 13.78 & 15.18 & 10.35 & 14.57 & 13.56 & 15.63 \\
\hline $\mathrm{CaO}$ & 0.29 & 0.17 & 0.37 & 0.22 & 0.25 & 0.25 & 0.29 & 0.35 & 0.17 & 0.31 & 0.36 & 0.02 & 0.24 & 0.26 & 0.31 & 0.03 & 0.22 & 0.22 & 0.29 \\
\hline $\mathrm{NiO}$ & 0.16 & 0.04 & 0.13 & 0.20 & 0.21 & 0.14 & 0.21 & 0.10 & 0.14 & 0.15 & 0.08 & 0.38 & 0.18 & 0.21 & 0.18 & 0.36 & 0.20 & 0.25 & 0.13 \\
\hline $\mathrm{MnO}$ & 0.29 & 0.40 & 0.35 & 0.28 & 0.23 & 0.30 & 0.27 & 0.36 & 0.49 & 0.33 & 0.51 & 0.14 & 0.28 & 0.26 & 0.27 & 0.15 & 0.23 & 0.24 & 0.32 \\
\hline Total & 99.87 & 99.78 & 99.74 & 100.01 & 99.83 & 99.40 & 100.12 & 100.06 & 98.66 & 99.01 & 99.39 & 99.52 & 99.53 & 99.42 & 99.72 & 99.76 & 99.78 & 99.56 & 99.13 \\
\hline Fo (mol\%) & 82.04 & 67.51 & 81.60 & 83.36 & 85.30 & 80.34 & 84.17 & 80.74 & 72.54 & 81.47 & 76.40 & 89.97 & 82.86 & 85.28 & 83.76 & 89.16 & 84.42 & 85.54 & 83.02 \\
\hline
\end{tabular}

3

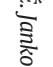

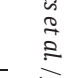



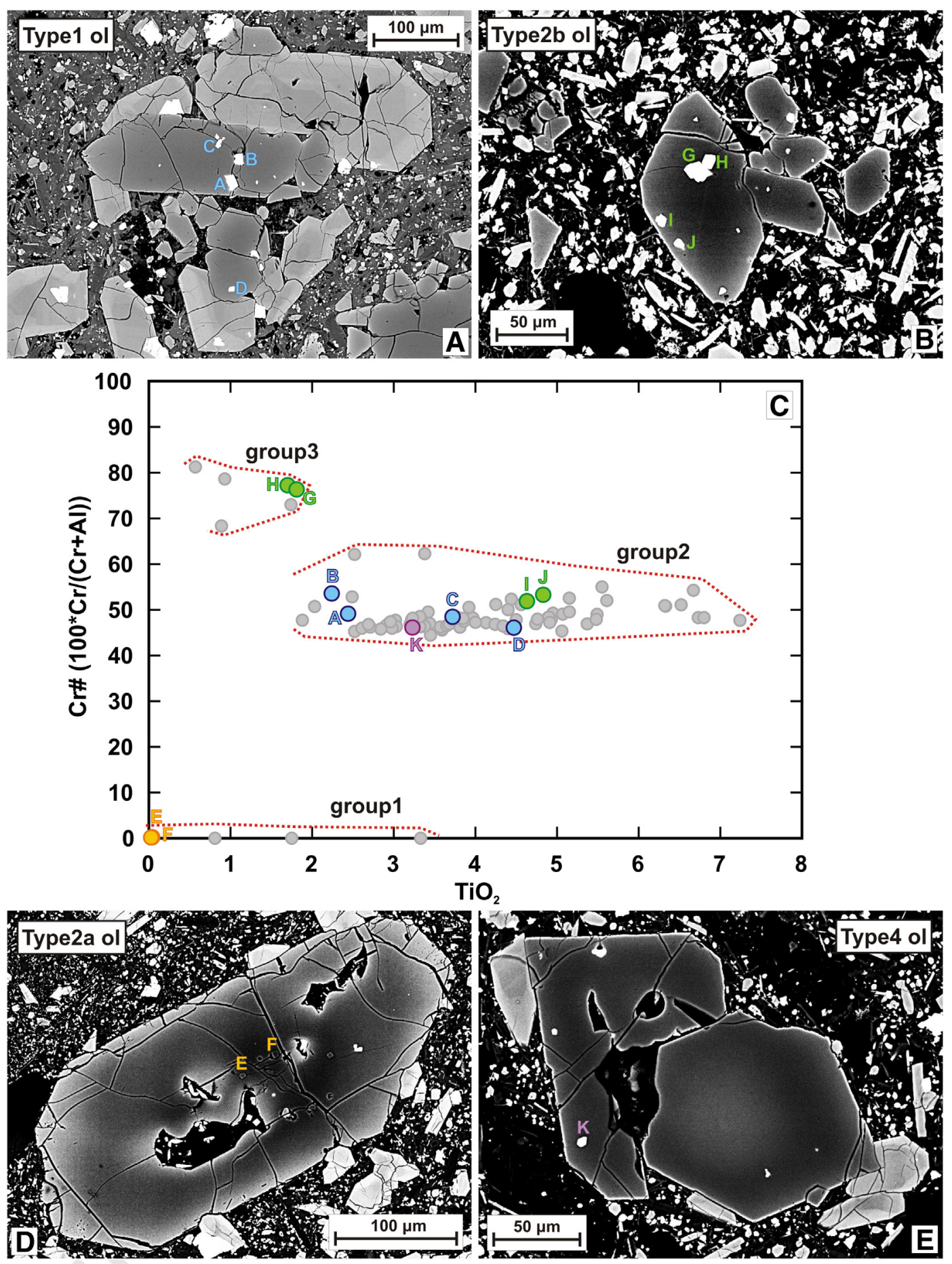

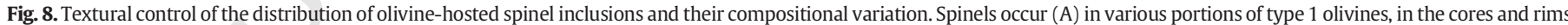

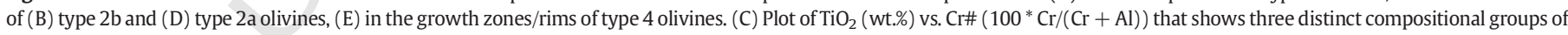
the studied spinels. The coloured points with letters indicate the compositions of spinels which are marked with coloured letters in the BSE images.

Table 4 contains representative compositions of the studied clinopyroxenes; they are ferroan diopsides (according to the I.M.A. classification of pyroxenes; Morimoto et al., 1988). Their Mg\#s $\left(\mathrm{Mg} /\left(\mathrm{Mg}+\mathrm{Fe}^{\mathrm{tot}}\right)\right)$ ranges from 0.65 to 0.84 which decrease with increasing $\mathrm{TiO}_{2}$ (1-5.5 wt.\%) and decreasing $\mathrm{Cr}_{2} \mathrm{O}_{3}$ (0-0.97 wt.\%) contents. These compositional variations follow the normal pyroxene fractionation trend (e.g., Tracy and Robinson, 1977). In addition, the observed trends reflect their sector zoning feature: the two trends represent the compositional variation of the Ti-rich and Ti-poor sectors
(Fig. 5C) (Dobosi et al., 1991). The clinopyroxene compositions and 479 trends of the three eruptive units are very similar (Fig. 5C).

7.4. Glass

481

Glass compositions were measured from the fresh sideromelane 482 glass shards of the lapilli tuff samples of unit 1 and from groundmass 483 glasses of the scoria and bomb samples of unit 3 (Table 5). The glass in 484 the sideromelane shards (unit 1) are fairly homogeneous and have 485 
t4.1 Table 3

t4.2 Representative analyses of the studied spinel inclusions in olivines.

$\mathrm{t} 4.3$

$\mathrm{t} 4.4$

$\mathrm{t} 4.5$

$\mathrm{t} 4.6$

$\mathrm{t} 4.7$

$\mathrm{t} 4.8$

$\mathrm{t} 4.9$

$\mathrm{t} 4.10$

$\mathrm{t} 4.11$

$\mathrm{t} 4.12$

$\mathrm{t} 4.13$

$\mathrm{t} 4.14$

t4.15

t4.16

$\mathrm{t} 4.17$

\begin{tabular}{|c|c|c|c|c|c|c|c|c|c|}
\hline & \multicolumn{3}{|c|}{ Group 1 sp } & \multicolumn{3}{|c|}{ Group $2 \mathrm{sp}$} & \multicolumn{3}{|c|}{ Group $3 \mathrm{sp}$} \\
\hline & $\mathrm{sp} 1$ & $\mathrm{sp} 2$ & sp3 & $\mathrm{sp} 4$ & sp5 & sp6 & sp7 & sp8 & sp9 \\
\hline $\mathrm{SiO}_{2}$ & 0.68 & 0.13 & 1.28 & 0.08 & 0.08 & 0.09 & 0.09 & 0.07 & 0.07 \\
\hline $\mathrm{TiO}_{2}$ & 1.75 & 0.04 & 0.05 & 2.61 & 4.13 & 5.61 & 1.81 & 0.57 & 0.93 \\
\hline $\mathrm{Al}_{2} \mathrm{O}_{3}$ & 60.71 & 63.11 & 61.09 & 21.59 & 17.28 & 12.95 & 9.64 & 7.91 & 8.86 \\
\hline $\mathrm{Cr}_{2} \mathrm{O}_{3}$ & 0.01 & 0.21 & 0.02 & 27.38 & 22.99 & 20.95 & 46.29 & 51.14 & 48.59 \\
\hline $\mathrm{Fe}_{2} \mathrm{O}_{3}$ & 5.45 & 5.27 & 6.12 & 15.95 & 20.44 & 24.72 & 10.62 & 7.84 & 10.15 \\
\hline $\mathrm{FeO}$ & 5.74 & 9.18 & 9.15 & 18.98 & 20.65 & 23.34 & 18.54 & 23.53 & 21.19 \\
\hline $\mathrm{MnO}$ & 0.08 & 0.11 & 0.12 & 0.27 & 0.30 & 0.35 & 0.25 & 0.45 & 0.30 \\
\hline $\mathrm{MgO}$ & 24.78 & 21.26 & 22.18 & 11.64 & 10.47 & 9.25 & 10.07 & 5.86 & 7.88 \\
\hline $\mathrm{NiO}$ & 0.00 & 0.12 & 0.13 & 0.18 & 0.18 & 0.17 & 0.12 & 0.02 & 0.09 \\
\hline Total & 99.19 & 99.44 & 100.14 & 98.83 & 96.57 & 97.62 & 97.47 & 97.39 & 98.06 \\
\hline Mg\# & 0.88 & 0.80 & 0.81 & 0.52 & 0.47 & 0.41 & 0.49 & 0.31 & 0.40 \\
\hline $\mathrm{Cr} \#$ & 0.01 & 0.22 & 0.02 & 45.96 & 47.16 & 52.03 & 76.32 & 81.26 & 78.63 \\
\hline
\end{tabular}

$\mathrm{Fe}_{2} \mathrm{O}_{3}$ is calculated on the basis of stoichiometry; $\mathrm{Mg} \#=\mathrm{Mg} /\left(\mathrm{Mg}+\mathrm{Fe}^{2+}\right)$; $\mathrm{Cr} \#=$ $100^{*} \mathrm{Cr} /(\mathrm{Cr}+\mathrm{Al}) ; \mathrm{sp}=$ spinel.

phonotephritic compositions (Fig. 3A) with 3.1-3.3 wt.\% MgO, while the groundmass glasses (unit 3 ) have more variable and more evolved tephriphonolitic compositions (Fig. 3A) with 1.1-2.3 wt.\% MgO.

\section{Thermobarometry}

Mineral-melt thermobarometric calculations were performed to estimate the pressures and temperatures of clinopyroxene crystallization. We applied the clinopyroxene-melt geothermobarometer of Putirka et al. (2003) which is based on the jadeite-diopside/hedenbergiteliquid and jadeite-liquid exchange equilibrium. The standard error of estimate of this calibration is $1.7 \mathrm{kbar}$ and $33^{\circ} \mathrm{C}$. For the calculations we used the compositions of clinopyroxene rims and glasses, i.e., we estimated the conditions of the last equilibration. All of the studied clinopyroxene crystals show sector zoning which is a common feature of clinopyroxenes in basaltic rocks. As the two sectors grow contemporaneously from the same liquid (e.g., Wass, 1973), the appropriate way for using these crystals for the calculations is to measure their rim compositions in both sectors and average these values for each crystal.

Pressure and temperature values were calculated for all of the three studied eruptive units which contain the same clinopyroxene population, i.e., their clinopyroxene rim compositions are very similar. In order to test whether the melt compositions are in equilibrium with the clinopyroxene rim compositions, first the observed and predicted values of clinopyroxene components (DiHd, EnFs, CaTs) were compared. Predicted components were obtained by the clinopyroxene saturation model of Putirka (1999) which should be matched by the measured components within the $\pm 2 \sigma$ level. Additionally, we tested the $\mathrm{Fe}-\mathrm{Mg}$ exchange equilibrium between clinopyroxene and melt: 512 $\mathrm{K}_{\mathrm{D}}(\mathrm{Fe}-\mathrm{Mg}$ ) are expected to be $0.28 \pm 0.08$ (Putirka, 2008). For unit 1513 we used the average glass composition of the sideromelane glass shards 514 (which show a restricted range of compositions) from the lapilli tuff 515 samples; for unit 2 there are not any available glass compositions be- 516 cause of the high crystallinity of the groundmass of the lava samples; 517 for unit 3 we used the compositions of the groundmass glasses. 518 Clinopyroxene-liquid pairs of unit 1 are in equilibrium with each 519 other; however, those of unit 3 failed the equilibrium tests because 520 the compositions of the groundmass glasses are too evolved to be in 521 equilibrium with the clinopyroxene rims.

Fig. 3C shows that the glass compositions of the sideromelane shards 523 can be derived from the whole-rock compositions through olivine +524 clinopyroxene crystallization, and the more evolved groundmass glass 525 compositions can be the result of additional clinopyroxene crystalliza- 526 tion. This suggests that in the case of unit 2-unit 3 the average glass 527 composition of the sideromelane shards from unit 1 can be also used 528 as an appropriate liquid composition that is in equilibrium with all of 529 the measured clinopyroxene rim compositions of each unit.

For all of the three units the thermobarometric calculations yield 531 pressures ranging from 5.2 to 8.5 kbar with an average of $6.6 \pm 532$ 0.9 kbar. Calculated crystallization temperatures range between 1058533 and $1089{ }^{\circ} \mathrm{C}$ (with an average of $1071 \pm 8^{\circ} \mathrm{C}$ ).

\section{Discussion}

\subsection{Sources for the diverse olivine and spinel populations}

Olivine crystals of the studied samples from the three eruptive units 537 show a large diversity of textures, zoning patterns and compositions 538 (Figs. 5-7) reflecting a complex evolution history of the deep magmatic 539 system in which both open- and closed-system processes operated. 540 Fig. 10 summarises the characteristics of the different olivine types 541 together with our interpretations concerning their origin and history. 542

Type 1 olivine crystals (Fig. 10A) being the most frequent olivine 543 type in each eruptive unit and based on their textures and chemistry 544 (Figs. 6A and 7), represent the olivine phenocryst s.s. (phenocryst 545 sensu stricto) phases, i.e., the olivines which grew in situ from the host 546 magma. However, the observed core-to-rim zoning in the case of the 547 other olivine types (Figs. 7 and 10B-F) must have been caused by per- 548 turbations in intensive variables over their history. Since the $\mathrm{Fe}^{2+} / \mathrm{Mg} 549$ ratio of the liquid has the dominant control on the Fo content (Roeder 550 and Emslie, 1970), significant steps in Fo within a given olivine crystal 551 must be due to changes in the composition or oxidation state of the 552 liquid. In the case of the type 2, type 3, type 4 and type 5 olivines the ob- 553 served zoning in Fo is accompanied by variations in $\mathrm{Ca}$ and $\mathrm{Ni}$, which are 554 insensitive to $\mathrm{fO}_{2}$. Thus, we conclude that these zoning characteristics 555
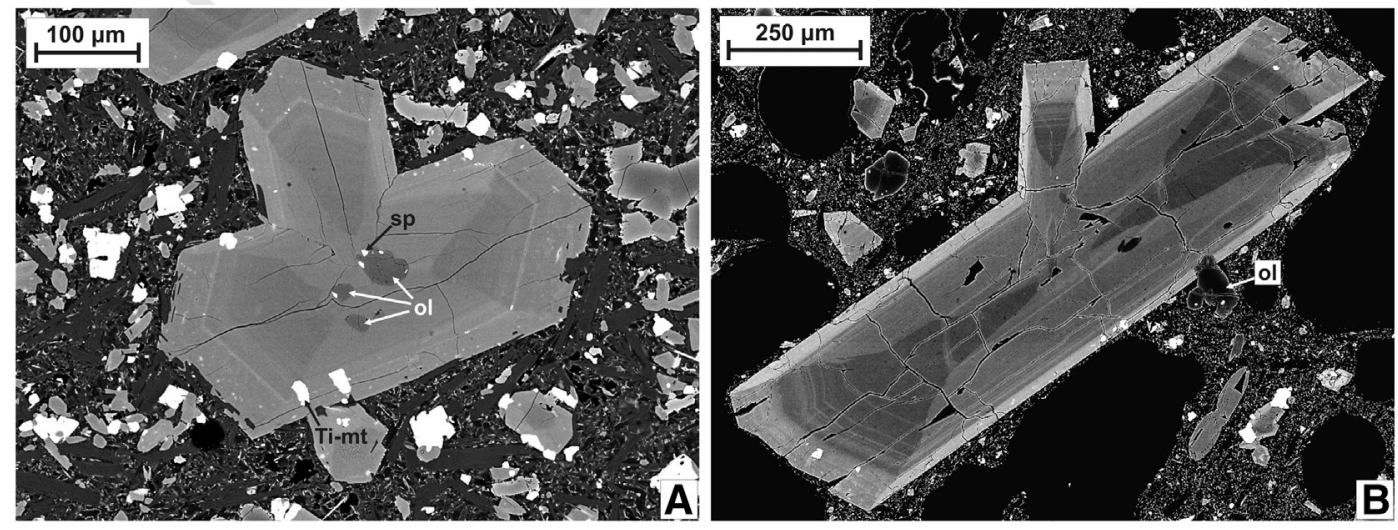

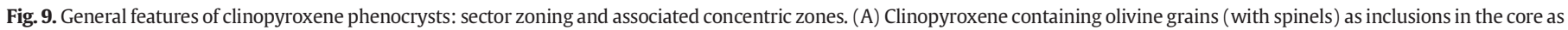
well as Ti-magnetite inclusions in the rim; (B) large clinopyroxene phenocryst and a partly enclosed small olivine in its rim. Ol, olivine; sp, spinel; Ti-mt, titanomagnetite. 
Representative compositions of the studied clinopyroxenes.

t5. 3

Table 5

Representative analyses of the studied glasses (normalised to $100 \%$ on a volatile-free basis).

\begin{tabular}{|c|c|c|c|c|c|c|}
\hline & \multicolumn{3}{|c|}{ Sideromelane glass shard } & \multicolumn{3}{|c|}{ Groundmass glass } \\
\hline & gl1 & gl2 & gl3 & gl4 & gl5 & gl6 \\
\hline $\mathrm{SiO}_{2}$ & 48.15 & 47.50 & 48.38 & 49.79 & 51.69 & 50.85 \\
\hline $\mathrm{TiO}_{2}$ & 2.45 & 2.39 & 2.35 & 2.18 & 2.01 & 1.91 \\
\hline $\mathrm{Al}_{2} \mathrm{O}_{3}$ & 19.03 & 19.09 & 19.32 & 20.47 & 22.06 & 21.54 \\
\hline $\mathrm{FeO}^{\text {tot }}$ & 8.75 & 8.59 & 8.81 & 8.67 & 6.50 & 7.22 \\
\hline $\mathrm{MgO}$ & 3.32 & 3.19 & 2.98 & 2.34 & 1.27 & 1.60 \\
\hline $\mathrm{MnO}$ & 0.18 & 0.19 & 0.19 & 0.15 & 0.17 & 0.15 \\
\hline $\mathrm{CaO}$ & 8.20 & 8.31 & 7.41 & 4.15 & 4.65 & 5.06 \\
\hline $\mathrm{Na}_{2} \mathrm{O}$ & 4.89 & 5.81 & 5.55 & 4.99 & 3.27 & 4.19 \\
\hline $\mathrm{K}_{2} \mathrm{O}$ & 3.58 & 3.57 & 3.76 & 5.95 & 7.27 & 6.35 \\
\hline $\mathrm{P}_{2} \mathrm{O}_{5}$ & 1.27 & 1.17 & 1.10 & 1.14 & 0.88 & 0.94 \\
\hline Mg\# & 40.32 & 39.85 & 37.58 & 32.46 & 25.84 & 28.37 \\
\hline
\end{tabular}

$\mathrm{FeO}^{\text {tot }}=$ total amount of iron; $\mathrm{Mg \#}=$ molar $\mathrm{MgO} /(\mathrm{MgO}+\mathrm{FeOtot}) ; \mathrm{gl}=$ glass

Fe2O3 is calculated on the basis of stoichiometry; $\mathrm{Mg} \#=\mathrm{Mg} /\left(\mathrm{Mg}+\mathrm{Fe}^{\mathrm{tot}}\right)$; $\mathrm{cpx}=$ clinopyroxene.

are the result of open-system processes involving multiple melts of different compositions.

Type 2 olivines (Figs. 6B and 10B, C) contain a resorbed high-Mg core whose xenocrystic origin can be ruled out due to their higher $\mathrm{CaO}$ $0.62 \mathrm{wt} . \%)$ and variable $\mathrm{NiO}(0-0.41 \mathrm{wt} . \%)$ contents. In addition, the shapes, sizes and compositions of the spinel inclusions encapsulated in these cores clearly infer that these olivines have magmatic origin. equently, they can be regarded as antecrysts, i.e., cognate crystals that originate from a magma genetically related to the one in which they are found. These antecrysts are surrounded by rims of phenocryst . origin.

The anhedral, resorbed high-Fo, low-CaO, high-NiO cores of type 3 and type 5 olivines (Figs. 6C, F and 10D, F) have compositions characteristic for olivines found in lithospheric mantle-derived peridotites xenocrysts derived from the wall rock in the lithospheric mantle which are overgrown by magmatic olivine (as described also in the of eruptive centres from the western Pannonian Basin; Jankovics et al., 2013). Occasionally, these olivine cores contain (enstatite) inclusions (Fig. 6F) and in some cases pyroxene (enstatite) crystals are also attached to anhedral olivines having compositions very similar to those of the magnesian cores of (e.g., Embey-Isztin et al., 2001), this observation also support the lithospheric mantle origin for the cores of the type 3 and type 5 olivines. In the case of type 3 crystals the skeletal overgrowth rim is only of

\begin{tabular}{|c|c|c|c|c|c|c|c|}
\hline \multicolumn{4}{|l|}{ cpx2 } & \multicolumn{4}{|l|}{ cpx3 } \\
\hline \multicolumn{2}{|c|}{ Sector 1} & \multicolumn{2}{|c|}{ Sector 2} & \multicolumn{2}{|c|}{ Sector 1} & \multicolumn{2}{|c|}{ Sector 2} \\
\hline Core & Rim & Core & Rim & Core & Rim & Core & Rim \\
\hline 50.53 & 47.48 & 47.32 & 43.13 & 50.86 & 47.14 & 47.21 & 43.08 \\
\hline 1.18 & 2.37 & 2.12 & 4.00 & 1.05 & 2.29 & 1.99 & 4.10 \\
\hline 3.62 & 5.40 & 6.65 & 9.22 & 3.47 & 5.80 & 6.72 & 9.54 \\
\hline 0.43 & 0.00 & 0.60 & 0.02 & 0.57 & 0.00 & 0.95 & 0.00 \\
\hline 2.36 & 3.26 & 3.34 & 5.71 & 1.61 & 3.73 & 3.08 & 4.85 \\
\hline 3.22 & 4.16 & 2.94 & 2.70 & 3.66 & 3.56 & 2.99 & 3.63 \\
\hline 0.11 & 0.17 & 0.11 & 0.14 & 0.14 & 0.15 & 0.10 & 0.11 \\
\hline 15.11 & 13.12 & 13.23 & 11.10 & 15.33 & 12.99 & 13.31 & 11.03 \\
\hline 22.63 & 23.08 & 22.74 & 23.07 & 22.40 & 23.24 & 22.35 & 22.88 \\
\hline 0.48 & 0.35 & 0.59 & 0.64 & 0.41 & 0.38 & 0.60 & 0.54 \\
\hline 99.69 & 99.39 & 99.63 & 99.77 & 99.51 & 99.31 & 99.30 & 99.76 \\
\hline 0.83 & 0.77 & 0.80 & 0.72 & 0.84 & 0.77 & 0.80 & 0.71 \\
\hline 43.87 & 38.84 & 40.13 & 34.53 & 44.60 & 38.59 & 40.75 & 34.44 \\
\hline 47.24 & 49.10 & 49.58 & 51.56 & 46.83 & 49.63 & 49.18 & 51.36 \\
\hline 8.88 & 12.06 & 10.29 & 13.91 & 8.57 & 11.79 & 10.08 & 14.20 \\
\hline
\end{tabular}
(e.g., Boudier, 1991; Hirano et al., 2004). Thus, they represent olivine (e.g., $\mathrm{Mg} \#\left(\mathrm{Fe}^{\mathrm{tot}}\right)=0.91$ ) characteristic for mantle-derived peridotites phenocryst S.S. origin, however, the cores of type 5 olivines are 583 surrounded by a rounded lower-Fo growth zone followed by the pheno- 584 crystic (s.s.) final rim. This latter feature indicate that the xenocrystic 585 cores of type 5 olivines were incorporated by a more evolved (com- 586 pared to the host) magma and then a final rim crystallised from the 587 host magma (phenocryst s.s.).

588

The reverse zoning itself indicates open-system processes (Streck, 589 2008 ) in the case of type 4 olivines (Figs. 6D-E and 10E). The resorbed 590 cores of these olivines can be characterised by variable Fo contents 591 (66-85 mol\%) and represent antecrysts (antecryst2; Fig. 7) deriving 592 from a magma other than the host. The often normally zoned rims sur- 593 rounding these cores have phenocryst s.s. origin. Cores of reversely 594 zoned olivines can represent crystals which were formed through 595 magma differentiation in a magma reservoir/storage zone. The more 596 magnesian growth bands and rims (i.e., the normally zoned rims) sur- 597 rounding these cores can be attributed to the arrival of more primitive 598 magma into the more evolved reservoir (replenishment) followed by 599 crystal fractionation (e.g., Kahl et al., 2011; Martí et al., 2013).

600

The diverse olivine populations are accompanied by the variety of 601 spinel inclusions. Group 2 spinels representing the dominant spinel 602 group can be regarded as phenocryst s.s. phases based on their abun- 603 dances, appearance and chemistry (Fig. 8A, C). They are included in all 604 portions of type 1 olivines and in the rims of the other olivine types 605 (Fig. 10). The within-group chemical variation of these spinels (rapidly 606 increasing $\mathrm{TiO}_{2}$ and $\mathrm{Fe}^{3+}$ contents and restricted range of $\mathrm{Cr} \#$ ) reflects 607 the effect of fractional crystallization of olivine that was the only 608 phase co-precipitating with spinel (the studied clinopyroxenes contain 609 titanomagnetites).

The cores of type $2 \mathrm{a}$ (Fig. 10B) and type $2 \mathrm{~b}$ (Fig. 10C) olivines contain 611 spinel inclusions of very different compositions: the former have group 612 1 spinels, while the latter have group 3 spinels (Fig. 8B-D). Such a strik- 613 ingly large difference (more than 68 in their $\mathrm{Cr} \# \mathrm{~s}$ ) that is observed be- 614 tween the compositions of group 1 and group 3 spinels is inconsistent 615 with crystallization from the same melt (e.g., Sack and Ghiorso, 1991). 616 Since the composition of spinel depends primarily on the melt compo- 617 sition (e.g., Irvine, 1965, 1967; Dick and Bullen, 1984; Allan et al., 618 1988; Arai, 1992; Roeder, 1994; Kamenetsky et al., 2001), this signifi- 619 cant difference in the Cr\#s more likely reflects the group 1 and group 620 3 spinels having precipitated from two distinct melts characterised by 621 different compositions. This means that the cores of type 2a olivines to- 622 gether with the group 1 spinels and the cores of type $2 \mathrm{~b}$ olivines togeth- 623 er with the group 3 spinels crystallised from two separate primitive 624 magmas of dissimilar compositions. Thus, the cores of the type 2a and 625 type $2 \mathrm{~b}$ olivine crystals do not represent antecrysts of the same origin 626 (antecryst 1a and antecryst 1b; Fig. 7). 


\begin{tabular}{|c|c|c|c|c|c|c|}
\hline & ol type & zoning & texture & features & sp incl. & interpretation \\
\hline $\mathbf{A}$ & Type1 & normal & & $\begin{array}{l}\text { euhedral-subhedral, } \\
\text { skeletal, Fo decreases } \\
\text { gradually rimward from } \\
86 \text { to } 75 \mathrm{~mol} \%\end{array}$ & $\begin{array}{l}\text { group2 } \mathrm{sp} \\
\text { in all portions }\end{array}$ & $\begin{array}{l}\text { phenocryst s.s.; } \\
\text { crystallization from M3 }\end{array}$ \\
\hline B & Type2a & normal & & $\begin{array}{l}\text { core: subhedral-anhedral, } \\
\text { resorbed, } 86-95 \text { mol } \% \text { Fo; } \\
\text { rim: euhedral-subhedral, } \\
\text { skeletal, } 80-85 \text { mol\% Fo }\end{array}$ & $\begin{array}{l}\text { group1 sp } \\
\text { in the core, } \\
\text { group2 sp } \\
\text { in the rim }\end{array}$ & $\begin{array}{l}\text { core: antecryst1a; } \\
\text { rim: phenocryst s.s.; } \\
\text { crystallization history: } \\
\mathrm{M} 1 \mathrm{a} \rightarrow \mathrm{M} 3\end{array}$ \\
\hline C & Type2b & normal & & $\begin{array}{l}\text { core: subhedral-anhedral, } \\
\text { resorbed, } 86-91 \text { mol\% Fo; } \\
\text { rim: euhedral-subhedral, } \\
\text { skeletal, } 80-85 \text { mol\% Fo }\end{array}$ & $\begin{array}{l}\text { group3 sp } \\
\text { in the core, } \\
\text { group2 sp } \\
\text { in the rim }\end{array}$ & $\begin{array}{l}\text { core: antecryst } 1 \mathrm{~b} \text {; } \\
\text { rim: phenocryst s.s.; } \\
\text { crystallization history: } \\
\mathrm{M} 1 \mathrm{~b} \rightarrow \mathrm{M} 3\end{array}$ \\
\hline D & Type3 & normal & & $\begin{array}{l}\text { core: anhedral, resorbed, } \\
89-91 \text { mol\% Fo; } \\
\text { rim: skeletal, } 79-85 \text { mol\% Fo }\end{array}$ & $\begin{array}{l}\text { group2 sp } \\
\text { in the rim }\end{array}$ & $\begin{array}{l}\text { core: xenocryst; } \\
\text { rim: phenocryst s.s.; } \\
\text { history: xenocryst } \\
\text { incorporation } \rightarrow \text { M3 }\end{array}$ \\
\hline $\mathbf{E}$ & Type4 & reverse & & $\begin{array}{l}\text { core: subhedral-anhedral, } \\
\text { resorbed, } 66-85 \text { mol\% Fo; } \\
\text { rim: euhedral-subhedral, } \\
\text { skeletal, } 76-86 \text { mol\% Fo }\end{array}$ & $\begin{array}{l}\text { group2 sp } \\
\text { in the rim }\end{array}$ & $\begin{array}{l}\text { core: antecryst2; } \\
\text { rim: phenocryst s.s.; } \\
\text { crystallization history: } \\
\text { M2 } \rightarrow \text { M3 }\end{array}$ \\
\hline$F$ & Type5 & multiple & & $\begin{array}{l}\text { core: anhedral, resorbed, } \\
89-90 \text { mol\% Fo; growth zone: } \\
\text { subhedral, } 83-85 \text { mol\% Fo; } \\
\text { rim: skeletal, } 82-86 \text { mol\% Fo }\end{array}$ & $\begin{array}{l}\text { group2 sp } \\
\text { in the rim }\end{array}$ & $\begin{array}{l}\text { core: xenocryst; growth zone: } \\
\text { antecryst2; rim: phenocryst } \\
\text { s.s.; history: xenocryst } \\
\text { incorporation } \rightarrow \mathrm{M} 2 \rightarrow \mathrm{M} 3\end{array}$ \\
\hline
\end{tabular}

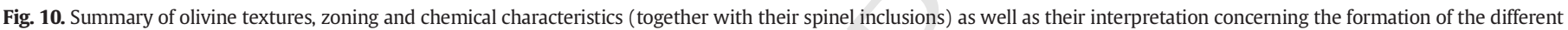
olivine types. M1a = magma 1a, M1b = magma 1b, M2 = magma 2, M3 = magma 3 which refer to the four magmatic environments

In mafic and ultramafic volcanic rocks Cr-rich spinel (15-70 wt.\% $\mathrm{Cr}_{2} \mathrm{O}_{3}$ ) is the most common spinel having compositions very similar to those of our group 2 and group 3 spinels. However, Al-rich spinels $\left(\mathrm{Cr} \#<5, \mathrm{Al}_{2} \mathrm{O}_{3}>50 \mathrm{wt}\right.$.\%) are rare in terrestrial volcanic rocks. Al-rich spinels similar to our group 1 spinels were rarely described from scarce continental mafic intrusions, lamproites, kimberlites and carbonatites (Barnes and Roeder, 2001) as well as from some primitive arc volcanics (Della-Pasqua et al., 1995). In the latter case, they also described coexisting $\mathrm{Cr}$-rich and Al-rich spinels (as inclusions in olivines) which were inferred to have crystallised from melts of different compositions.

\subsection{Magmatic environments and processes}

The large variety of the olivine and spinel crystals, i.e., the liquidus phases indicates a complex magmatic system with four magmatic environments (Figs. 10 and 11) beneath the small-volume Kissomlyó volcano. The antecrystic cores of type $2 \mathrm{a}$ and type $2 \mathrm{~b}$ olivines (i.e., antecryst $1 \mathrm{a}$ and antecryst $1 \mathrm{~b}$ ) derive from two primitive magmas (called magma 1a and magma $1 \mathrm{~b}$ ) characterised by different compositions based on the chemistry (group 1 and group 3 ) of their spinel inclusions. These primitive olivines and spinels probably represent the earliest stage of the evolution of the magmatic system. Differentiation of magma 1a through fractional crystallization of antecryst 1a olivine together with group 1 spinel and that of magma $1 \mathrm{~b}$ through fractional crystallization of antecryst $1 \mathrm{~b}$ olivine together with group 3 spinel could have taken place in the deepest part of the magmatic system. The majority of these early crystals were probably removed but a part of them were recycled by subsequent magma packets. On the basis of the studied olivines and spinels (Figs. 5-8) magma 1a could have been present in the system only during the second evolutionary phase, but magma $1 \mathrm{~b}$ is inferred to have been involved during both evolutionary phases of the magmatic system.

The antecrystic cores of type 4 olivines (i.e., antecryst 2 ) could have been formed through magma differentiation in the shallower part of the system and are related to another magma, called magma 2 . The reversely zoned feature of these olivines suggests magma recharge. As 661 recorded by the compositions of their normally zoned rims the recharge 662 magma is represented by the already differentiated magmas formed at 663 deeper levels. This recharge magma recycled a number of more evolved 664 olivine antecrysts and became dominant in the system. This dominant 665 magma (representing the host magma) is called magma 3 from which 666 type 1 olivines, the rims of each of the other olivine types and group 2667 spinels crystallised followed by the formation of clinopyroxene pheno- 668 crysts as indicated by the textural relationships between olivines and 669 clinopyroxenes.

Lithospheric mantle-derived olivine xenocrysts were incorporated 671 by magma 2 and magma 3 recorded by type 5 and type 3 olivine crys- 672 tals, respectively. This suggests that olivine crystallization from both 673 magma 2 and magma 3 occurred in the lithospheric mantle. 674

The highly variable core compositions of the reversely zoned oliv- 675 ines and the recycling of different olivine antecrysts suggest that the 676 evolution of the magmatic system could have been characterised by 677 the involvement of multiple small magma. In addition, the variety of 678 core compositions of reversely zoned olivines suggests that the mafic 679 magmas could have been variably differentiated before a new more 680 primitive magma intrusion arrived from depth. For simplicity, magma 681 1a, magma 1b, magma 2 and magma 3 refer to the four different mag- 682 matic environments (including the several small magma packets) 683 where the distinct olivine and spinel populations crystallised.

In summary, the evolution of the magmatic system beneath 685 Kissomlyó involved a complex set of petrogenetic processes: fractional 686 crystallization, olivine ( + spinel) recycling, xenocryst incorporation, 687 magma recharge and interaction of small magma packets, and each of 688 these processes was operating during the whole life of the system. 689 Through the stratigraphic succession, the juvenile basalt fragments of 690 unit 1 contain the largest amount of reversely zoned olivines, i.e., the 691 magma batch of the first eruption cycle brought the highest amount of 692 antecryst 2 olivines to the surface. Based on this observation the forma- 693 tion of these more evolved olivine crystals could have been the most 694 dominant during the first evolutionary phase, when magma packets 695 


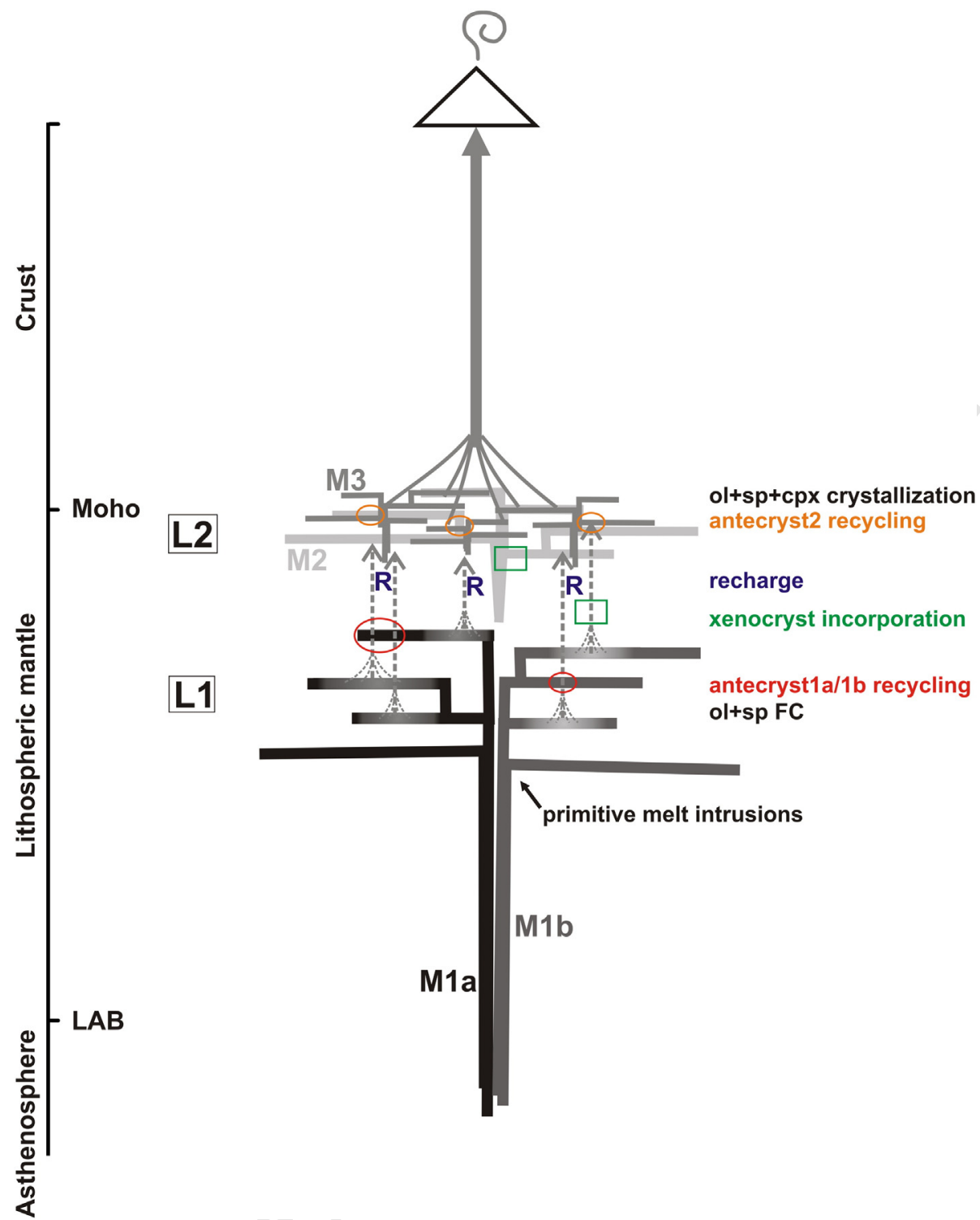

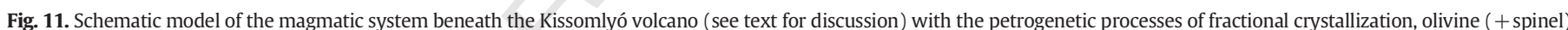

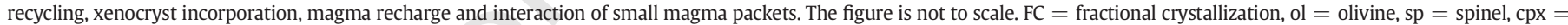

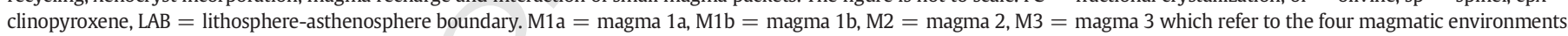

accumulated and trapped at a possible rheological/density boundary giving way to magma differentiation.

\subsection{Multi-level magmatic system}

On the basis of the revealed magmatic environments and deepseated petrogenetic processes we propose a multi-level magmatic system beneath Kissomlyó (Fig. 11). It consists of two levels (level 1 and level 2) which are assumed being separated. At level 1 primitive magma intrusions occurred which went through olivine and spinel fractional crystallization resulting in the formation of fractionated melts. These melts ascended upwards, recycled primitive olivine antecrysts (antecrysts $1 \mathrm{a}$ and $1 \mathrm{~b}$ ) and recharged level 2 where they recycled antecryst 2 olivines from magma 2 . This was followed by the in situ crystallization of olivine + spinel and subsequent clinopyroxene (at level 2).

Based on experimental studies carried out on alkaline basalts, olivine crystallises as a liquidus phase (together with spinel) only at pressures $\leq 10$ kbar (e.g., Green and Ringwood, 1967). This corresponds to depths $\leq \sim 37 \mathrm{~km}$ which means that level 1 of the system where early 713 olivine + spinel crystallised from primitive magmas was located at 714 depths of maximum $\sim 37 \mathrm{~km}$, i.e., in the upper part of the lithospheric 715 mantle, considering that the crustal thickness is around $26-27 \mathrm{~km}$ be- 716 neath the studied locality (Horváth, 1993).

Pressure values obtaining from clinopyroxene-melt barometry using 718 clinopyroxene rim and coexisting glass compositions are generally 719 interpreted as major levels of magma fractionation (e.g., Schwarz 720 et al., 2004; Klügel et al., 2005; Galipp et al., 2006; Stroncik et al., 721 2009; Hildner et al., 2012). This method was used for numerous ocean 722 island basalts (see the former references) and its good applicability 723 was confirmed by the nice correlation of barometric results with geo- 724 physical data in the case of the recent El Hierro activity (Longpré et al., 725 2014).

The estimated pressure values reflect the conditions of last 727 clinopyroxene-melt equilibration which is $6.6 \pm 0.9$ kbar average pres- 728 sure in our case. This corresponds to a depth of about $25 \mathrm{~km}$ that can 729 be placed just above the Moho (i.e., in the lowermost part of the 730 crust). Since these data reflect the equilibrium conditions between 731 
clinopyroxene rims and host melt (i.e., final clinopyroxene-melt equilibration), deeper fractionation for the clinopyroxene cores are possible (e.g., Hildner et al., 2012).

The textural relationships between olivine and clinopyroxene crystals indicate that the crystallization of olivines usually preceded that of clinopyroxenes. This can suggest that each type of olivines could have been formed at greater depths than clinopyroxenes, i.e., around and below the crust-mantle boundary. As level 1 is placed to a maximum depth of $\sim 37 \mathrm{~km}$, the lower boundary of the magmatic system is expected to be at depths $\leq \sim 37 \mathrm{~km}$, while its upper boundary (the upper part of level 2) is given by the $\sim 25 \mathrm{~km}$ depth indicated by the final clinopyroxene-melt equilibration. The exact extent of level 1 and level 2 cannot be determined.

A similar model of a multi-stage system consisting of a deeper and a shallower reservoir was presented in the case of the 2011-2012 El Hierro submarine activity on the strong basis of petrological, thermobarometric and seismic data (Martí et al., 2013; Longpré et al., 2014). They also described several types of olivines characterised by different zoning patterns, which were also inferred to bear evidence of open-system processes like magma replenishment and mixing.

\subsection{What represents the whole-rock composition?}

The whole-rock geochemical data of the three studied eruptive units (Fig. 3) do not show any abrupt, significant differences, thus the erupted magmas were compositionally similar during the entire volcanic activity. Although the compositional variation of the whole-rock data (Fig. 3C-F) do not indicate any complexities and could be explained by fractional crystallization of olivine + spinel, the high-resolution investigation of mineral textures, zoning and chemistry unravelled the complex evolution of the deep magmatic system. The erupted magma compositions represented by the bulk rock geochemistry are the results of various, closed- and open-system petrogenetic processes and interaction of multiple small magma packets in a multi-level system. The observed small differences between the whole-rock geochemistry of unit 1 and unit 2-unit 3 are most likely due to the variation in the proportions of the petrogenetic processes acting in the system during the two evolutionary phases.

Distinct eruptive units observed through basaltic monogenetic sequences are generally interpreted as representing discrete magma batches of different characteristics on the basis of their whole-rock geochemistry (e.g., Brenna et al., 2010; Mcgee et al., 2012; Sohn et al.,
2012). These magma batches were also inferred to have interacted/ 772 mixed with each other based on the presence of units having whole- 773 rock compositions transitional between those of the discrete magma 774 batches. Brenna et al. (2012) described a bimodal distribution of olivine 775 Fo contents and a wide whole-rock variation at Songaksan volcano (Jeju 776 Island Volcanic Field). Based on these observations they proposed a 777 model of mixing of ascending magma pulses (in a main plumbing con- 778 duit) which evolved in independent dykes before. However, in order to 779 recognise the exact relationship between these magmas and to reveal 780 the processes occurring during their ascent a detailed investigation of 781 the olivine textures, zoning and chemistry would be necessary. It is im- 782 portant to note that through the analyses of whole-rock samples only 783 the features of the erupted magma batches can be recognised, however, 784 through the detailed mineral-scale investigations we can reveal the 785 exact formation of these erupted magma batches, i.e., what kind of 786 magmas (magma packets) were involved in the magmatic system and 787 through which processes have they undergone ultimately resulting in 788 a given erupted magma batch.

789

Our study indicates that the observed three eruptive units of 790 Kissomlyó represent distinct magma batches having similar composi- 791 tions but each magma erupted to the surface in the two main eruptive 792 phases (represented by unit 1 and unit $2+$ unit 3 ) is composed of sev- 793 eral small magma packets which have interacted with each other in 794 both evolutionary phases.

Whilst the whole-rock geochemical data show a relatively small 796 variation (60.4-65.7 Mg\#), the Fo contents of the cores of the mag- 797 matic (i.e., of type 1 , type $2 \mathrm{a}+$ type $2 \mathrm{~b}$ and type 4 ) olivines have a 798 much broader range of compositions $\left(\mathrm{Fo}_{66-91}\right)$ indicating equilibri- 799 um liquid Mg\#s ranging from 36 to 74 (Fig. 12). This large variation 800 is due to the involvement of the four magmatic environments 801 (magma 1a + magma 1b, magma 2 and magma 3 ) crystallising the 802 different olivine (and spinel) populations. The very Fo-rich olivine 803 clot (Fig. 6B) was excluded from the equilibrium liquid Mg\# calcula- 804 tion because of its too high Fo content that may suggest a non- 805 eqilibrium/non-ideal/different $\mathrm{K}_{\mathrm{D}}(\mathrm{Fe}-\mathrm{Mg})$ in this case. However, 806 their enclosed spinel inclusions indicate that they have magmatic 807 origin and belong to the antecryst 1a population.

\subsection{Comparison with other monogenetic sequences}

Fig. 4 shows a comparison with other monogenetic eruptive centres: 810 the Crater Hill (Smith et al., 2008) and Motukorea (Mcgee et al., 2012) in 811

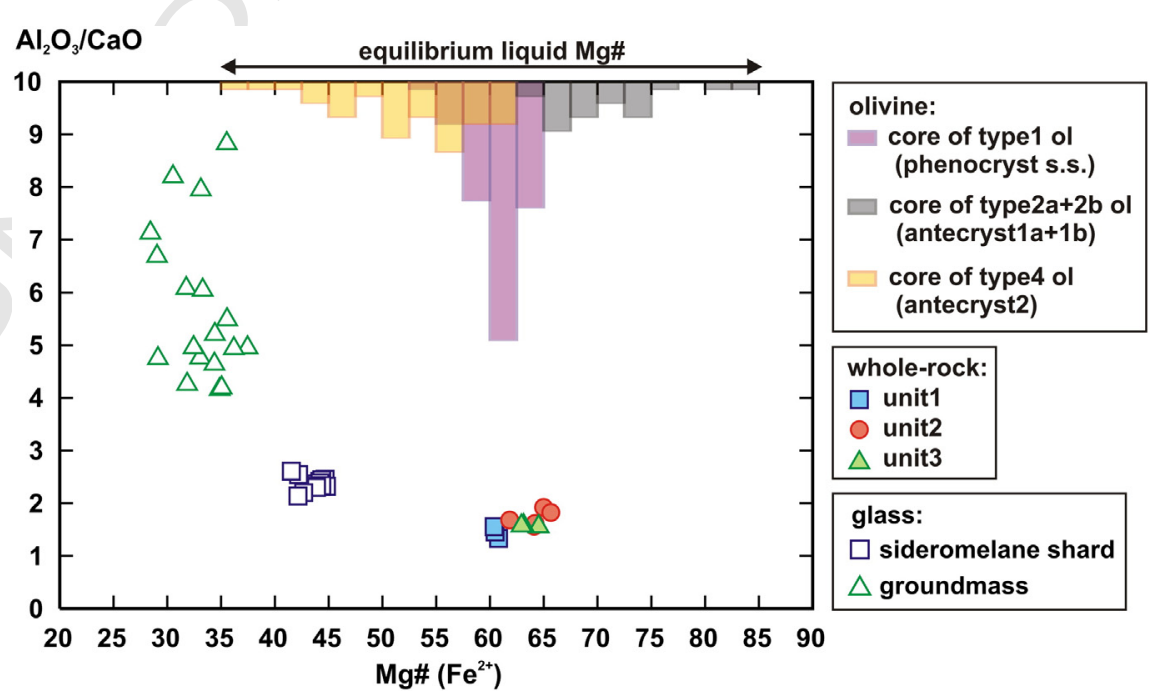

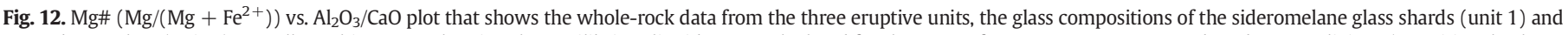

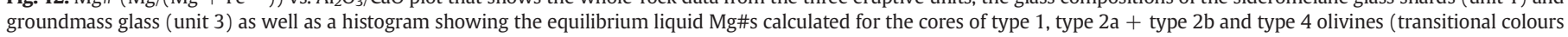

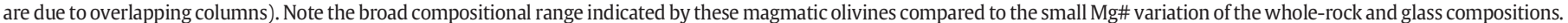


the Auckland Volcanic Field, the Udo volcano (Brenna et al., 2010), the Songaksan volcanic centre (Brenna et al., 2011) and the Ilchulbong tuff cone (Sohn et al., 2012), all of the latter three located in the Jeju Island Volcanic Field. Additionally, we included the case of the 2011-2012 El Hierro activity, Canary Islands (analysed samples: from 15 October 2011 to 28 January 2012; Martí et al., 2013) that also represents a monogenetic event. In the case of these eruptive centres the presented geochemical datasets are the results of a higher-resolution sampling. This can be explained by the presence of several discontinuity surfaces/event horizons through their sequences (resulted in the recognition of several subunits) and by the larger volumes of these volcanics comparing to those of Kissomlyó. Nevertheless, our dataset is comparable with these because our sampling was appropriate for the given scale. The detailed studies on the mentioned volcanic centres do not infer significant time gap(s) during their volcanic activities, i.e., their evolution reflect a short period of time (within days to months). However, significant compositional variations were observed through time/successions between and/or within the individual eruptive units. Although most of them show fluctuations in their compositional evolutions, their trends have a significant reverse part moving towards more primitive compositions through time/the units upward in the sequence. These compositional variations suggest that monogenetic eruptive centres are fed by dynamically changing magmatic systems. It is notable, that in the case of the Kissomlyó volcano, where a considerable time gap is assumed in the volcanic activity (recorded by the lacustrine sediments between the tuff ring pyroclastics and the lava flow) the observable chemical variation is smaller than those of the others.

In the evolution of a magmatic system the volume of the involved magmas can have an important role: in the case of low-volume magmas they cool and quench rapidly which do not enable significant magmatic differentiation. The Kissomlyó volcanic centre can be characterised by a small total eruptive volume $\left(\sim 0.002 \mathrm{~km}^{3}\right)$ and if we consider separately the volumes of the individual eruptive units $\left(\sim 0.001 \mathrm{~km}^{3}\right)$ it would be expected that the magma supply could have been very low. However, the eruptive volume seen on the surface does not represent the real volume of magmas being involved in the evolution of the deep magmatic system beneath the volcanoes. Therefore, the magma productivity can be significantly larger than what is indicated by the total eruptive volume. This could be feasible in the case of the Kissomlyó volcanic centre where the whole-rock compositions as well as the presence of abundant clinopyroxene phenocrysts and more evolved olivine antecrysts indicate fairly considerable magmatic differentiation.

The relationship between the sizes and compositions of eruptive centres was studied in the case of the Auckland Volcanic Field, New Zealand by Mcgee et al. (2013) who found strong correlations and concluded that the size of a volcanic centre is controlled by processes in the deep asthenosphere. However, they have not discussed the relationship between the size (eruptive volume) of volcanic centres and their intracentre compositional variations. Based on their presented dataset the compositional variations within the eruptive centres do not depend on the eruptive volumes: a small centre can be characterised by the same significant chemical variation that is observed in the case of a large centre and also a large centre can have a compositional variation smaller than that of a small centre. Volcanic centres showing a small intra-centre chemical variation similar to that of Kissomlyó are rare. Additionally, the centre having very similar small eruptive volume shows much larger intra-centre compositional variation than Kissomlyó.

All of these imply that although the Kissomlyó volcano has a very small eruptive volume and a small intra-centre whole-rock chemical variation its deep magmatic system was characterised by a complex evolution history.

\section{Conclusions}

The evolution of the magmatic system beneath the small-volume Kissomlyó monogenetic volcano was inferred as being complex documented by mineral textures, zoning and chemistry. Five different 876 types of olivine crystals and three distinct compositional groups of 877 olivine-hosted spinel inclusions were recognised which represent four 878 magmatic environments. These crystals bear evidence of several petro- 879 genetic processes that played role in the formation of the erupted 880 magma batches: fractional crystallization, olivine ( + spinel) recycling, 881 lithospheric mantle-derived xenocryst incorporation, magma recharge 882 and interaction of multiple small magma packets.

883

Reversely zoned olivines suggest the presence of evolved magmas, 884 while high-Fo olivine cores imply primitive magmas at depth which 885 did not erupt to the surface but are detectable by the olivine antecrysts 886 found in the host magma.

Barometric results of final clinopyroxene-melt equilibration indi- 888 cate that clinopyroxene crystallization could have occurred around the 889 Moho, which was preceded by the formation of the diverse olivine 890 crystals.

Our study implies that the petrogenesis of a single magma batch 892 (usually defined as representing a given eruptive unit) can be complex 893 involving several magmas and various, closed- and open-system mag- 894 matic processes which finally result in the whole-rock (erupted 895 magma) composition.

896

Beyond the bulk rock geochemistry, the high-resolution investiga- 897 tion of the textures, zoning and chemistry of minerals through the se- 898 quence of monogenetic volcanoes provides a more detailed insight 899 into the deep magmatic processes and into the characteristics of the 900 magmas being involved in the evolution of the magmatic system. Such 901 a detailed mineral-scale analysis is a very useful tool that yields a lot 902 of important knowledge about the magmatic system which are essen- 903 tial to our better understanding about the evolution of "simple" basaltic 904 monogenetic systems.

\section{Uncited reference}

Valentine and Perry, 2007

\section{Acknowledgements}

We are very grateful to Lucy E. McGee and Marco Brenna for their 909 careful reviews, valuable suggestions and comments which helped to 910 substantially improve the first version of the manuscript. The editor 911 Margaret T. Mangan is also acknowledged for her useful advice. In this 912 research M. Éva Jankovics was supported by the European Union and 913 the State of Hungary, co-financed by the European Social Fund in the 914 framework of TÁMOP 4.2.4. A/2-11-1-2012-0001 'National Excellence 915 Program'. The TÉT_10-1-2011-0694 project (Hungarian-Austrian Coop- 916 eration) provided partial financial support. Zsolt Bendő and Franz Kiraly 917 are acknowledged for their help during the SEM and EMPA analyses. 918

\section{References}

Ali, S., Ntaflos, T., 2011. Alkali basalts from Burgenland, Austria: petrological constraints 920 on the origin of the westernmost magmatism in the Carpathian-Pannonian Region. 921 Lithos 121 (1-4), 176-188.

Allan, J.F., Sack, R.O., Batiza, R., 1988. Cr-rich spinels as petrogenetic indicators; MORB- 923 type lavas from the Lamont seamount chain, eastern Pacific. Am. Mineral. 73 (7-8), 924 741-753.

Arai, S., 1992. Chemistry of chromian spinel in volcanic rocks as a potential guide to 926 magma chemistry. Mineral. Mag. 56, 173-184. 927

Auer, A., Martin, U., Németh, K., 2007. The Fekete-hegy (Balaton Highland Hungary) "soft- 928 substrate" and "hard-substrate" maar volcanoes in an aligned volcanic complex - 929 Implications for vent geometry, subsurface stratigraphy and the palaeoenvironmental 930 setting. J. Volcanol. Geotherm. Res. 159 (1-3), 225-245. 931

Bada, G., Horváth, F., 2001. On the structure and tectonic of the Pannonian Basin and 932 surrounding orogens. Acta Geol. Hung. 44 (2-3), 301-327.

Balogh, K., Árva-Sós, E., Pécskay, Z., Ravasz-Baranyai, L., 1986. K/Ar dating of post- 934 Sarmatian alkali basaltic rocks in Hungary. Acta Mineral. Petrogr. Szeged. 28, 75-93. 935

Barnes, S.J., Roeder, P.L., 2001. The range of spinel compositions in terrestrial mafic and 936 ultramafic rocks. J. Petrol. 42 (12), 2279-2302.

Boudier, F., 1991. Olivine xenocrysts in picritic magmas: an experimental and microstruc- 938 tural study. Contrib. Mineral. Petrol. 109 (1), 114-123. 
Boyce, J., Nicholls, I., Keays, R., Hayman, P., 2015. Variation in parental magmas of Mt Rouse, a complex polymagmatic monogenetic volcano in the basaltic intraplate Newer Volcanics Province, southeast Australia. Contrib. Mineral. Petrol. 169 (2), 1-21.

Brenna, M., Cronin, S.J., Smith, I.E.M., Sohn, Y.K., Németh, K., 2010. Mechanisms driving polymagmatic activity at a monogenetic volcano, Udo, Jeju Island, South Korea. Contrib. Mineral. Petrol. 160 (6), 931-950.

Brenna, M., Cronin, S.J., Németh, K., Smith, I.E.M., Sohn, Y.K., 2011. The Influence of Magma Plumbing Complexity on Monogenetic Eruptions, Jeju Island, Korea. Terra Nova. pp. $1-6$.

Brenna, M., Cronin, S.J., Smith, I.E.M., Maas, R., Sohn, Y.K., 2012. How small-volume basaltic magmatic systems develop: a case study from the Jeju Island Volcanic Field, Korea. J. Petrol. 53 (5), 985-1018.

Connor, C.B., Conway, F.M., 2000. Basaltic Volcanic Fields. In: Sigurdsson, H. (Ed.), Encyclopedia of Volcanoes. Academic Press, San Diego, pp. 331-343.

Csontos, L., Nagymarosy, A., Horváth, F., Kovác, M., 1992. Tertiary evolution of the IntraCarpathian area: a model. Tectonophysics 208 (1-3), 221-241.

Della-Pasqua, F.N., Kamenetsky, V.S., Gasparon, M., Crawford, A.J., Varne, R., 1995. Al-spinels in primitive arc volcanics. Mineral. Petrol. 53 (1-3), 1-26.

Dick, H.J.B., Bullen, T., 1984. Chromian spinel as a petrogenetic indicator in abyssal and alpine-type peridotites and spatially associated lavas. Contrib. Mineral. Petrol. 86 (1), 54-76.

Dobosi, G., 1989. Clinopyroxene zoning patterns in the young alkali basalts of Hungary and their petrogenetic significance. Contrib. Mineral. Petrol. 101, 112-121.

Dobosi, G., Schultz-Güttler, R., Kurat, G., Kracher, A., 1991. Pyroxene chemistry and evolution of alkali basaltic rocks from Burgenland and Styria, Austria. Mineral. Petrol. 43 (4), 275-292.

Embey-Isztin, A., Downes, H., James, D.E., Upton, B.G.J., Dobosi, G., Ingram, G.A., Harmon, R.S., Scharbert, H.G., 1993. The petrogenesis of Pliocene alkaline volcanic rocks from the Pannonian Basin, Eastern Central Europe. J. Petrol. 34, 317-343.

Embey-Isztin, A., Dobosi, G., Altherr, R., Meyer, H.-P., 2001. Thermal evolution of the lithosphere beneath the western Pannonian Basin: evidence from deep-seated xenoliths. Tectonophysics 331 (3), 285-306.

Erlund, E.J., Cashman, K.V., Wallace, P.J., Pioli, L., Rosi, M., Johnson, E., Granados, H.D., 2010 Compositional evolution of magma from Parícutin Volcano, Mexico: the tephra record. J. Volcanol. Geotherm. Res. $197(1-4), 167-187$.

Fodor, L., Csontos, L., Bada, G., Benkovics, L., Györfi, I., 1999. Tertiary tectonic evolution of the Carpatho-Pannonian region: a new synthesis of palaeostress data. In: Durand, B., Jolivet, L.F.H., Séranne, M. (Eds.), The Mediterranean basins: tertiary extension within the Alpine Orogen. Geological Society, London, Special Publications 156, pp. 295-334.

Galipp, K., Klügel, A., Hansteen, T.H., 2006. Changing depths of magma fractionation and stagnation during the evolution of an oceanic island volcano: La Palma (Canary Islands). J. Volcanol. Geotherm. Res. 155 (3-4), 285-306.

Ginibre, C., Wörner, G., Kronz, A., 2007. Crystal zoning as an archive for magma evolution. Elements 3 (4), 261-266.

Granet, M., Wilson, M., Achauer, U., 1995. Imaging a mantle plume beneath the French Massif Central. Earth Planet. Sci. Lett. 136 (3-4), 281-296.

Green, D.H., Ringwood, A.E., 1967. The genesis of basaltic magmas. Contrib. Mineral. Petrol. $15(2), 103-190$

Harangi, S., 2001a. Neogene to quaternary volcanism of the Carpathian-Pannonian region-a review. Acta Geol. Hung. 44, 223-258.

Harangi, S., 2001b. Neogene magmatism in the Alpine-Pannonian Transition Zone-a model for melt generation in a complex geodynamic setting. Acta Vulcanol. 13, 25-39.

Harangi, S., 2001c. Volcanology and petrology of the Late Miocene to Pliocene alkali basaltic volcanism in the Western Pannonian Basin. In: Ádám, A., Szarka, L. (Eds.), PANCARDI 2001 Field Guide, Sopron, pp. 51-81.

Harangi, S., 2009. Volcanism of the Carpathian-Pannonian region, Europe: the role of subduction, extension and mantle plumes. http://www.mantleplumes.org/ CarpathianPannonian.html.

Harangi, S., Lenkey, L., 2007. Genesis of the Neogene to Quaternary volcanism in the Carpathian-Pannonian region: role of subduction, extension, and mantle plume. Geol. Soc. Am. Spec. Pap. 418, 67-92.

Harangi, S., Vaseili, O., Kovács, R., Tonarini, S., Coradossi, N., Ferraro, D., 1994. Volcanological and magmatological studies on the Neogene basaltic volcanoes of the Southern Little Hungarian Plain, Pannonian Basin (Western Hungary). Mineral. Petrogr. Acta 37, 183-197.

arangi, S., Vaselli, O., Tonarini, S., Szabó, C., Harangi, R., Coradossi, N., 1995. Petrogenesis of Neogene extension-related alkaline volcanic rocks of the Little Hungarian Plain Volcanic Field (Western Hungary). Acta Vulcanol. 7 (2), 173-187.

Harangi, S., Sági, T., Seghedi, I., Ntaflos, T., 2013. Origin of basaltic magmas of Perşani volcanic field, Romania: a combined whole rock and mineral scale investigation. Lithos 180-181, 43-57.

Harangi, S., Jankovics, M.É., Sági, T., Kiss, B., Lukács, R., Soós, I., 2014. Origin and geodynamic relationships of the Late Miocene to Quaternary alkaline basalt volcanism in the Pannonian basin, eastern-central Europe. Int. J. Earth Sci. 1-26.

Hildner, E., Klügel, A., Hansteen, T.H., 2012. Barometry of lavas from the 1951 eruption of Fogo, Cape Verde Islands: implications for historic and prehistoric magma plumbing systems. J. Volcanol. Geotherm. Res. 217-218, 73-90.

Hirano, N., Yamamoto, J., Kagi, H., Ishii, T., 2004. Young, olivine xenocryst-bearing alkalibasalt from the oceanward slope of the Japan Trench. Contrib. Mineral. Petrol. 148 (1), 47-54.

Hoernle, K., Zhang, Y.S., Graham, D., 1995. Seismic and geochemical evidence for largescale mantle upwelling beneath the eastern Atlantic and western and central Europe. Nature 374, 34-39.

rvath, F., 1993. Towards a mechanical model for the formation of the Pannonian Basin. Tectonophysics 226 (1-4), 333-357.
Horváth, F., 1995. Phases of compression during the evolution of the Pannonian Basin and 1026 its bearing on hydrocarbon exploration. Mar. Pet. Geol. 12 (8), 837-844. 1027

Horváth, F., Cloetingh, S., 1996. Stress-induced late-stage subsidence anomalies in the 1028 Pannonian Basin. Tectonophysics 266 (1-4), 287-300. 1029

Irvine, T.N.1 1965. Chromian spinel as a petrogenetic indicator: Part 1. Theory. Can.J. Earth 1030 Sci. 2 (6), 648-672.

Irvine, T.N., 1967. Chromian spinel as a petrogenetic indicator: Part 2. Petrologic applica- 1032 tions. Can. J. Earth Sci. 4 (1), 71-103. 1033

Jankovics, É., Harangi, S., Ntaflos, T., 2009. A mineral-scale investigation on the origin of 1034 the 2.6 Ma Füzes-tó basalt, Bakony-Balaton Highland Volcanic Field (Pannonian 1035 Basin, Hungary). Cen. Eur. Geol. 52 (2), 97-124. 1036

Jankovics, M.É.. Harangi, S., Kiss, B.., Ntaflos, T., 2012. Open-system evolution of the Füzes-tó 1037 alkaline basaltic magma, western Pannonian Basin: constraints from mineral textures 1038 and compositions. Lithos 140-141, 25-37.

Jankovics, MÉ, Dobosi, G. Embey-Isztin, A, Kiss, B. Sági, T. Harangi, S, Ntaflos, T, 2013, 1040 Origin and ascent history of unusually crystal-rich alkaline basaltic magmas from the 1041 western Pannonian Basin. Bull. Volcanol. 75 (9), 1-23. 1042

Jugovics, L., 1915. Az Alpok keleti végződése alján és a Vas vármegyei Kis Magyar Alföldön 1043 felbukkanó bazaltok és bazalttufák, I. rész (in Hungarian). Magyar Állami Földtani 1044 Intézet Évi Jelentésepp. 49-73. 1045

Jugovics, L., 1916. Az Alpok keleti végződése alján és a Vas vármegyei Kis Magyar Alföldön 1046 felbukkanó bazaltok és bazalttufák, II. rész (in Hungarian). Magyar Állami Földtani 1047 Intézet Évi Jelentésepp. 63-76. 1048

Jugovics, L., 1968. A dunántúli bazalt és bazalttufa területek (in Hungarian). A Magyar 1049 Állami Földtani Intézet Évi Jelentése az 1967pp. 75-82 évröl. 1050

Kahl, M., Chakraborty, S., Costa, F., Pompilio, M., 2011. Dynamic plumbing system beneath 1051 volcanoes revealed by kinetic modeling, and the connection to monitoring data: an 1052 example from Mt. Etna. Earth Planet. Sci. Lett. 308 (1-2), 11-22. 1053

Kamenetsky, V.S., Crawford, A.J., Meffre, S., 2001. Factors controlling chemistry of mag- 1054 matic spinel: an empirical study of associated olivine, $\mathrm{Cr}$-spinel and melt inclusions 1055 from primitive rocks. J. Petrol. 42 (4), 655-671.

Kereszturi, G., Csillag, G., Németh, K., Sebe, K., Balogh, K., Jáger V., 2010. Volcanic architec- 1057 ture, eruption mechanism and landform evolution of a Plio/Pleistocene intra- 1058 continental basaltic polycyclic monogenetic volcano from the Bakony-Balaton 1059 Highland Volcanic Field, Hungary. Cent. Eur. J. Geosci. 2 (3), 362-384. 1060

Kereszturi, G. Németh, K. Cronin, S.J., Agustín-Flores, J., Smith, I.E.M., Lindsay, J., 2013. A 1061 model for calculating eruptive volumes for monogenetic volcanoes - Implication 1062 for the Quaternary Auckland Volcanic Field, New Zealand. J. Volcanol. Geotherm. 1063 Res. 266, 16-33.

1064

Klügel, A. Hansteen, T.H. Galipp, K. 2005. Magma storage and underplating beneath 1065 Cumbre Vieja volcano, La Palma (Canary Islands). Earth Planet. Sci. Lett. 236 (1-2), 1066 211-226.

Konečný, V., Lexa, J. Balogh, K. Konečný, P., 1995. Alkali basalt volcanism in Southern 1068 Slovakia: volcanic forms and time evolution. Acta Vulcanol. 7 (2), 167-171. 1069

Lenkey, L., Dövényi, P., Horváth, F., Cloetingh, S., 2002. Geothermics of the Pannonian 1070 Basin and its bearing on the neotectonics. European Geophysical Union Stephan 1071 Mueller Special Publications, Series 3 pp. 29-40. 1072

Longpré, M.-A., Klügel, A., Diehl, A., Stix, J., 2014. Mixing in mantle magma reservoirs prior 1073 to and during the 2011-2012 eruption at El Hierro, Canary Islands. Geology 42 (4), 1074 $315-318$

Martí, J., Castro, A., Rodríguez, C., Costa, F., Carrasquilla, S., Pedreira, R., Bolos, X., 2013. 1076 Correlation of magma evolution and geophysical monitoring during the 2011-2012 1077 El Hierro (Canary Islands) Submarine Eruption. J. Petrol. 54 (7), 1349-1373. 1078

Martin, U., Németh, K., 2004. Mio/Pliocene Phreatomagmatic Volcanism in the Western 1079 Pannonian Basin. Geological Institute of Hungary, Budapest. 1080

Martin, U., Németh, K., 2005. Eruptive and depositional history of a Pliocene tuff ring that 1081 developed in a fluvio-lacustrine basin: Kissomlyó volcano (western Hungary). 1082 J. Volcanol. Geotherm. Res. 147 (3-4), 342-356.

Mcgee, L., Beier, C., Smith, I.M., Turner, S., 2011. Dynamics of melting beneath a small- 1084 scale basaltic system: a U-Th-Ra study from Rangitoto volcano, Auckland volcanic 1085 field, New Zealand. Contrib. Mineral. Petrol. 162 (3), 547-563. 1086

Mcgee, L.E., Millet, M.-A., Smith, I.E.M., Németh, K., Lindsay, J.M., 2012. The inception and 1087 progression of melting in a monogenetic eruption: Motukorea Volcano, the Auckland 1088 Volcanic Field, New Zealand. Lithos 155, 360-374.

Vcee, LE Smith, IEM Z Millet, M-A, Handley, H.K. Lindsay JM, 2013. Asthenospheic control of melting processes in a monogenetic basaltic system: a case study of the 1091 Auckland Volcanic Field, New Zealand. J. Petrol. 54 (10), 2125-2153. 1092

Morimoto, N., Fabries, J., Ferguson, A.K., Ginzburg, I.V., Ross, M., Seifert, F.A., Zussman, J., 1093 Aoki, K., Gottardi, G., 1988. Nomenclature of pyroxenes. Mineral. Mag. 52, 535-550. 1094 Nakamura, N., 1974. Determination of REE, Ba, Fe, Mg, Na and K in carbonaceous and 1095 ordinary chondrites. Geochim. Cosmochim. Acta 38 (5), 757-775.

Needham, A.J., Lindsay, J.M., Smith, I.E.M., Augustinus, P., Shane, P.A., 2011. Sequential 1097 eruption of alkaline and sub-alkaline magmas from a small monogenetic volcano in 1098 the Auckland Volcanic Field, New Zealand. J. Volcanol. Geotherm. Res. 201 (1-4), 1099 126-142.

Németh, K., 2010. Monogenetic volcanic fields: origin, sedimentary record, and relationship with polygenetic volcanism. Geol. Soc. Am. Spec. Pap. 470, 43-66.

1100

. (Pannonian Basin, Hungary). J. Volcanol. Geotherm. Res. 111 (1-4), 111-135. 110

Németh, K., Moufti, M.R., El-Masry, N., Qaddah, A., Pécskay, Z., 2014. Maars over cones: 1105 repeated volcanism in the same location along fissures in western Saudi Arabian 1106 volcanic fields. In: Carrasco-Núñez, G., Aranda-Gómez, JJ., Ort, M.H., Silva-Corona, 1107 J.J. (Eds.), 5th International Maar Conference. Universidad Nacional Autónoma de 1108 México, Centro de Geociencias, Juriquilla, Qro., México, pp. 2-3.

Putirka, K. 1999. Clinopyroxene + liquid equilibria to 100 kbar and $2450 \mathrm{~K}$ Contrib. 1110 Mineral. Petrol. 135 (2-3), 151-163.
1110 1111 
Putirka, K.D., 2008. Thermometers and barometers for volcanic systems. Rev. Mineral. Geochem. 69 (1), 61-120.

Putirka, K.D., Mikaelian, H., Ryerson, F., Shaw, H., 2003. New clinopyroxene-liquid thermobarometers for mafic, evolved, and volatile-bearing lava compositions, with applications to lavas from Tibet and the Snake River Plain, Idaho. Am. Mineral. 88 (10), 1542-1554

Reubi, O., Nicholls, I.A., Kamenetsky, V.S., 2003. Early mixing and mingling in the evolution of basaltic magmas: evidence from phenocryst assemblages, Slamet Volcano, Java, Indonesia. J. Volcanol. Geotherm. Res. 119 (1-4), 255-274.

Roeder, P.L., 1994. Chromite: from the fiery rain of chondrules to the Kilauea Iki lava lake. Can. Mineral. 32 (4), 729-746.

Roeder, P.L., Emslie, R.F., 1970. Olivine-liquid equilibrium. Contrib. Mineral. Petrol. 29 (4), 275-289.

Roeder, P.L., Poustovetov, A., Oskarsson, N., 2001. Growth forms and composition of chromian spinel in MORB magma: diffusion-controlled crystallization of chromian spinel. Can. Mineral. 39 (2), 397-416.

Roeder, P.L., Thornber, C., Poustovetov, A., Grant, A., 2003. Morphology and composition of spinel in Pu'u 'O'o lava (1996-1998), Kilauea volcano, Hawaii. J. Volcanol. Geotherm. Res. 123 (3-4), 245-265.

Roeder, P., Gofton, E., Thornber, C., 2006. Cotectic Proportions of Olivine and Spinel in Olivine-Tholeiitic Basalt and Evaluation of Pre-Eruptive Processes. J. Petrol. 47 (5), 883-900.

Sack, R.O., Ghiorso, M.S., 1991. Chromian spinels as petrogenetic indicators; thermodynamics and petrological applications. Am. Mineral. 76 (5-6), 827-847.

Schwarz, S., Klügel, A., Wohlgemuth-Ueberwasser, C., 2004. Melt extraction pathways and stagnation depths beneath the Madeira and Desertas rift zones (NE Atlantic) inferred from barometric studies. Contrib. Mineral. Petrol. 147 (2), 228-240.

Seghedi, I., Downes, H., Vaselli, O., Szakács, A., Balogh, K., Pécskay, Z., 2004. Post-collisional Tertiary-Quaternary mafic alkalic magmatism in the Carpathian-Pannonian region: a review. Tectonophysics 393 (1-4), 43-62.

Shane, P., Gehrels, M., Zawalna-Geer, A., Augustinus, P., Lindsay, J., Chaillou, I., 2013. Longevity of a small shield volcano revealed by crypto-tephra studies (Rangitoto volcano, New Zealand): change in eruptive behavior of a basaltic field. J. Volcanol. Geotherm. Res. 257, 174-183.

Smith, D.R., Leeman, W.P., 2005. Chromian spinel-olivine phase chemistry and the origin of primitive basalts of the southern Washington Cascades. J. Volcanol. Geotherm. Res. 140 (1-3), 49-66.
Smith, I.E.M., Blake, S., Wilson, C.J.N., Houghton, B.F., 2008. Deep-seated fractionation 1149 during the rise of a small-volume basalt magma batch: Crater Hill, Auckland, New 1150 Zealand. Contrib. Mineral. Petrol. 155 (4), 511-527.

Sohn, Y.K., Cronin, S.J., Brenna, M., Smith, I.E.M., Németh, K., White, J.D.L., Murtagh, R.M., 1152 Jeon, Y.M., Kwon, C.W., 2012. Ilchulbong tuff cone, Jeju Island, Korea, revisited: a 1153 compound monogenetic volcano involving multiple magma pulses, shifting vents, 1154 and discrete eruptive phases. Geol. Soc. Am. Bull. 124 (3-4), 259-274. 1155

Streck, M.J., 2008. Mineral textures and zoning as evidence for open system processes. 1156 Rev. Mineral. Geochem. 69 (1), 595-622.

Stroncik, N., Klügel, A., Hansteen, T., 2009. The magmatic plumbing system beneath El 1158 Hierro (Canary Islands): constraints from phenocrysts and naturally quenched basaltic 1159 glasses in submarine rocks. Contrib. Mineral. Petrol. 157 (5), 593-607.

Strong, M., Wolff, J., 2003. Compositional variations within scoria cones. Geology 31 (2), 1161 $143-146$.

Suhr, P. Goth, K, 2013. The Maar of Hammerunterwiesenthal-a “Complex Monogenetic 1163 Volcano”, Saxony. In: Büchner, J., Rapprich, V., Tietz, O. (Eds.), Basalt 2013 Cenozoic 1164 Magmatism in Central Europe. Czech Geological Survey Prague \& Senckenberg Museum 1165 of Natural History Görlitz, Görlitz, Germany, pp. 145-146. 1166

Takada, A., 1994. The influence of regional stress and magmatic input on styles of mono- 1167 genetic and polygenetic volcanism. J. Geophys. Res. 99 (B7), 13563-13573. 1168

Tari, G., Horváth, F., Rumpler, J., 1992. Styles of extension in the Pannonian Basin. 1169 Tectonophysics 208 (1-3), 203-219.

Tari, G., Dövényi, P., Horváth, F., Dunkl, I., Lenkey, L., Stefanescu, M., Szafián, P., Tóth, T., 1171 1999. Lithospheric structure of the Pannonian Basin derived from seismic, gravity 1172 and geothermal data. In: Durand, B., Jolivet, L., Horváth, F., Séranne, M. (Eds.), The 1173 Mediterranean basins: tertiary extension within the Alpine orogen. Geological 1174 Society, London, Special Publication 156, pp. 215-250.

Tracy, R.J., Robinson, P., 1977. Zoned titanian augite in alkali olivine basalt from Tahiti and 1176 the nature of titanium substitutions in augite. Am. Mineral. 62 (7-8), 634-645. 1177

Valentine, G.A., Perry, F.V., 2007. Tectonically controlled, time-predictable basaltic volca- 1178 nism from a lithospheric mantle source (central Basin and Range Province, USA). 1179 Earth Planet. Sci. Lett. 261 (1-2), 201-216. 1180

Wass, S.Y., 1973. The origin and petrogenetic significance of hour-glass zoning in titanif- 1181 erous clinopyroxenes. Mineral. Mag. 39 (302), 133-144. 1182

Wijbrans, J., Németh, K., Martin, U., Balogh, K., 2007. 40Ar/39Ar geochronology of 1183 Neogene phreatomagmatic volcanism in the western Pannonian Basin, Hungary. 1184 J. Volcanol. Geotherm. Res. 164 (4), 193-204. 